NOTES

\title{
DOES THE NCAA PLAY FAIR? A DUE PROCESS ANALYSIS OF NCAA ENFORCEMENT REGULATIONS
}

\author{
ROBIN J. GREEN
}

\section{INTRODUCTION}

The 1992 NCAA Men's Basketball Championship Game was the most watched basketball game in television history. ${ }^{1}$ In addition to being very popular, college basketball has become extremely profitable. ${ }^{2}$ The tremendous rise in the popularity and profitability of college basketball and other college sports has led to increased concern about the fairness of the administration of collegiate athletics. The National Collegiate Athletic Association (NCAA), founded im 1906, oversees the administration of collegiate athletics and establishes the playing rules and regulations governing the behavior of member institutions and student-athletes. ${ }^{3}$ Its basic purpose is to "maintain intercollegiate athletics as an integral part of the educational program and the athlete as an integral part of the student body and, by so doing, retain a clear line of demarcation between intercollegiate athletics and profes-

1. Setting a record for a single collegiate or professional basketball game, 58 million television viewers watched Duke beat Michigan for the NCAA title. Steven Herbert, NCAA Final Sets U.S. TV Mark, L.A. TIMES, Apr. 8, 1992, at F2.

2. Non-television revenue generated by the 1992 NCAA Men's Basketball Championship Tournament exceeded \$11 million. 1992-93 General Operating Budget, NCAA NEWS, Sept. 2, 1992, at 13. Moreover, in 1992, the NCAA distributed over $\$ 73$ million to the membership froun its seven-year, \$1-billion television contract with CBS. Revenue Fund Pays out \$73.4 Million, NCAA NEWS, Sept. 14, 1992, at 1.

3. The NCAA maintains a full-time administrative staff and headquarters in Overland Park, Kansas. NATIONAL Collegiate ATHLETIC Association, 1992-1993 NCAA MANUAL 441-42 (1992) [hereinafter NCAA MANUAL]. The NCAA has become a multimillion-dollar organization. Its operating revenue in 1992-1993 is $\$ 166,308,300$, a six-percent increase over the previous year's figure. Budget's Direct Payments Top $\$ 106$ Million, NCAA NEWS, Sept. 2, 1992, at 1, 13. 
sional sports." The NCAA is comprised of "colleges, universities, athletics conferences or associations and other groups that are related to intercollegiate athletics." The responsibilities of its active ineinbers include compliance with the NCAA constitution, bylaws, and other legislation. ${ }^{6}$ In addition, active ineinbers must certify the eligibility of all student-athletes and must ban ineligible atlletes from competition. ${ }^{7}$ Consistent with its enforcement procedures, ${ }^{8}$ the NCAA may discipline active members who violate NCAA rules. ${ }^{9}$

All active and qualified member institutions control NCAA policies througl annual conventions. ${ }^{10}$ Between conventions, the ruling body of the NCAA is the 46-member NCAA Council, ${ }^{11}$ whose responsibilities include establishing the general policy of the association, reporting to the conventions, and interpreting NCAA regulations. ${ }^{12}$ The NCAA Council appoints a Committee on Infractions to administer the NCAA's enforcement prograin. ${ }^{13}$ The Committee's duties include considering complaints that a ineniber institution has failed to "meet the conditions and obligations of menibership,"14 determining facts related to alleged violations of NCAA regulations, ${ }^{15}$ imposing the appropriate penalties for inajor violations, ${ }^{16}$ establishing enforcement policies and procedures, ${ }^{17}$ and overseeing investigations of alleged rules violations. ${ }^{18}$ The

4. NCAA MANUAL, supra note 3, art. 1.3.1.

5. Id. art. 3.1.1. The NCAA's membership has steadily expanded, reaching a record total of 1,064 for the 1992-1993 academic year. Membership Total Sets Mark, NCAA NEws, Sept. 2, 1992, at 1.

6. NCAA MANUAL, supra note 3, art. 3.2.4.1.

7. Id. art. 3.2.4.3. II(B).

8. For a discussion of current NCAA enforcement procedures, see infra Section

9. NCAA MANUAL, supra note 3, art. 3.2.6. Two-thirds of the delegates present at the NCAA annual convention may terminate or suspend an imstitution's membership for failing to comply with NCAA rules. Id. arts. 3.2.5.1, 19.4.3.

10. NATIONAL COLlEgiate ATHLETIC ASSOCIATION, 1991-1992 GeNeRAL INFORMATION 2 (1991).

11. Id.

12. NCAA MANUAL, supra note 3, art. 4.1.3.

13. Id. art. 19.1.

14. Id. art. 19.1.3(a).

15. Id. art. 19.1.3(c).

16. Id. art. 19.1.3(d). The Committee on Infractions may also consider appeals of secondary violations. Id.

17. Id. art. 19.2. These procedures are subject to the Council's review.

18. See id. art. 19.1.3(e). 
NCAA enforcement staff works for the Committee on Infractions and is responsible for gathering the facts and presenting the NCAA's case at an investigative hearing. ${ }^{19}$

During the past few years there have been many highly-publicized cases of NCAA investigations involving major universities. ${ }^{20}$ An institution found guilty of violating NCAA rules could face adverse publicity ${ }_{2}^{21}$ lose revenue as consequences of penalties imposed, ${ }^{22}$ and suffer damage to its reputation. Although these repercussions have existed for many years, the decade-long dispute involving former University of Nevada at Las Vegas head basketball coach Jerry Tarkanian brought the fairness of NCAA enforcement procedures under the intense scrutiny of the media, the general public, and state and federal legislatures. In spite of public concern that the NCAA's complex regulations and virtual monopoly over collegiate athletics enable the NCAA to unilaterally prosecute and penalize any institution it chooses, the Supreme Court determined in NCAA v. Tarkanian ${ }^{23}$ that because the NCAA is not a state actor, it is not required to comply with due process. ${ }^{24}$ As a result, the Court refused to intervene in the NCAA's discipline of the university. However, since Tarkanian, public opinion has continued to push the $\mathrm{NCAA}^{25}$ and federal and state legislature $^{26}$ to reform NCAA procedures.

This Note considers, given this public cry for reform, what due process protections, if any, are missing from NCAA enforcement procedures, and whether state or federal legislation is the appropriate metlod for reforming NCAA enforcenient regulations.

19. See id. arts. 19,32 .

20. These institutions include the University of Florida, University of Illinois, University of Kentucky, University of Maryland, University of Missouri, University of Nevada at Las Vegas, North Carolina State University, and Syracuse University. efforts.

21. This negative publicity may inpede the institution's recruiting and fundraising

22. For example, the Committee on Infractions nay prohibit television coverage of athletic contests, forbid participation in post-season tournainents or competition, or require the refund of inoney received through the participation of an ineligible studentathlete. NCAA MANUAL, supra note 3, art. 19.4.2.1.

23. 488 U.S. 179 (1988). Tarkanian, in a suit that eventually reached the United States Supreme Court, claimed that the immense power of the NCAA enforcennent procedures should be limited by imposing due process protections. See id. at 181, 191-92.

24. Id. at 182, 199.

25. For a discussion of recent efforts to reform the NCAA's procedures, see infra Section II(C).

26. For a discussion of state and federal legislation, see infra Sections III(A)-(B). 
Part I outlines the legal issues surrounding the application of due process requirements to NCAA regulations. Although the NCAA is not a state actor, an understanding of traditional due process analysis is necessary to the evaluation of whetler there is a need for reforming NCAA enforcement procedures. Part II examines whether NCAA regulations would comply with due process requirements if the NCAA were a state actor. This Part argues that the majority of due process requirements are met by current rules, and that proposed reforms would cure most of the remaining deficiencies. Part III examines proposed and enacted state and federal legislation reforming NCAA regulations. This Note concludes that given the intrusiveness of such legislation, which will hikely lead to many NCAA challenges (such as the one to Nevada's due process legislation $)^{27}$ and the promising nature of the reforms that continue to be instituted by the NCAA, the NCAA should continue to oversee its own reform.

\section{Constitutional Ground Rules: Traditional Due PROCESS ANALYSIS}

Through the years various lawsuits have challenged the NCAA's enforcement procedures. ${ }^{28}$ The case that has generated the most publicity involved Jerry Tarkanian, former head basketball coach at the University of Nevada at Las Vegas (UNLV). Claiming that the NCAA had failed to provide lim with due process during its investigation of violations at UNLV, Tarkanian challenged NCAA enforcement regulations in a case mitiated in 1977 that reached the United States Supreme Court in 1988. ${ }^{29}$ The Supreme Court held that the NCAA was not a state actor, and therefore did not consider wliether NCAA regulations afforded Tarkanian due process. ${ }^{30}$ Section A discusses the Supreme

27. In NCAA v. Miller, 795 F. Supp. 1476, 1488 (D. Nev. 1992), the federal district court held in favor of the NCAA in ruling that the Nevada statute, which required the NCAA to conform to certain due process requirements, was unconstitutional under the Commerce and Contract Clauses of the United States Constitution and therefore invalid and unenforceable. See infra subsection $\operatorname{III}(\mathrm{A})(2)$.

28. E.g., Arlosoroff v. NCAA, 746 F.2d 1019 (4th Cir. 1984); Regents of Univ. of Minn. v. NCAA, 560 F.2d 352 (8th Cir.), cert. dismissed, 434 U.S. 978 (1977); Howard Univ. v. NCAA, 510 F.2d 213 (D.C. Cir. 1975); Parish v. NCAA, 506 F.2d 1028 (5th Cir. 1975).

29. NCAA v. Tarkanian, 488 U.S. 179, 181 (1988).

30. Id. at 182, 199. The Due Process Clause of the Fourteenth Amendment, which requires state actors to comply with due process, is inapplicable to those who are not 
Court's decision in Tarkanian. Although the Court held that neither the United States Constitution nor federal law requires the NCAA to comply with due process, state and federal legislatures are nonetheless attenipting to force the NCAA to implement due process protections. ${ }^{31}$ To establish a framework for evaluating current NCAA regulations and the necessity of legislative reform, Section $B$ analyzes how traditional due process requirements would apply to the NCAA were it a state actor.

\section{A. The State Actor Issue in NCAA v. Tarkanian}

In the early 1970s, the NCAA began investigating Tarkanian and UNLV for potential violations of NCAA rules. In 1976, the NCAA Committee on Infractions issued an Official Inquiry to UNLV that listed alleged NCAA rules violations and, as preparation for hearings on these charges, requested the University, a public institution, to conduct its own investigation into the alleged violations.

During four days of hearings, the NCAA's Committee on Infractions evaluated the NCAA enforcenient staff's evidence and UNLV's response. ${ }^{32}$ Prior to the hearings, UNLV's requests for disclosure of the sources and bases of the allegations had been denied. ${ }^{33}$ Tarkanian attended the hearings and was represented by counsel on two of the four days, but the persons making the allegations were not present for examination. An NCAA audiotape of the hearings, kept at NCAA headquarters in Kansas, provided the only record of the hearings. ${ }^{34}$

Following the hearings, the Committee on Infractions issued a confidential report that found thirty-eight violations of NCAA rules, including ten naming Tarkanian. ${ }^{35}$ The NCAA imposed

state actors. See, e.g., Blum v. Yaretsky, 457 U.S. 991, 1002 (1982); Lugar v. Edmondson Oil Co., 457 U.S. 922, 937 (1982); Rendell-Baker v. Kohn, 457 U.S. 830, 838 (1982).

31. Four states (Florida, Illinois, Nebraska, and Nevada) have enacted legislation requiring the NCAA to comply with due process. Eight states (California, Iowa, Kansas, Minnesota, Mississippi, New York, Rlode Island, and Soutl Carolina) and the House of Representatives have introduced similar legislation. See infra Sections III(A)-(B).

32. University of Nev. v. Tarkanian, 594 P.2d 1159, 1160 (Nev. 1979). UNLV's affidavits and sworn testimomies frequently confiicted witl the NCAA's evidence, which consisted primarily of investigators' recollections of conversations. UNLV also challenged the credibility of the NCAA investigators and infornants. Id. at 1161.

33. Id. at $1160-61$.

34. Id. at 1161.

35. NCAA v. Tarkanian, 488 U.S. $179,185-86$ (1988). The Official Inquiry originally 
penalties on the UNLV athletic program and directed the University to "show cause why additional penalties should not be imposed against UNLV" if it did not suspend Tarkanian from involvement with the athletic department durmg the University's probation. ${ }^{36}$ Alleging that the NCAA investigation and hearing had deprived him of liberty and property without due process, in violation of 42 U.S.C. $\& 1983,{ }^{37}$ Tarkanian challenged the NCAA enforcement regulations and the NCAA's attempt to force his suspension. ${ }^{38}$

In a 5-4 decision, the United States Supreme Court held that because the NCAA's investigations did not constitute state action, the NCAA was not a state actor for purposes of the Fourteenth 'Amendnient or 42 U.S.C. $\S 1983$, and therefore was not required to comply with due process. ${ }^{39}$ Although UNLV, as a public institution, engaged in state action when it adopted the NCAA regulations, it did not thereby transform the regulations into state rules, or the NCAA into a state actor. ${ }^{40}$ Additionally, because the NCAA did not force UNLV to conply with its recommendations ${ }^{41}$ but rather UNLV chose to comply with the NCAA regula-

alleged many other recruiting, academic, and eligibility violations by UNLV. The most serious charge asserted that Tarkanian attempted to impede the NCAA investigation. Id. at 186 n.9.

36. Id. at 186 . The NCAA bylaws limit the NCAA's authority to impose sanctions on member institutions and do not allow direct actions against a member institution's employees. Id. at 183-84 \& nn.6-7.

37. Id. at 187.

38. Tarkanian obtained an injunction in Nevada state court enjoining UNLV from enforcing the suspension. University of Nev. v. Tarkanian, 594 P.2d 1159 (1979). The Nevada Suprene Court affirmed the injunction. Tarkanian v. NCAA, 741 P.2d 1345 (1987). The NCAA appealed to the Supreme Court, which granted certiorari to decide, for the first time, whether the NCAA is a state actor. NCAA v. Tarkanian, 488 U.S. 179 (1988).

39. Tarkanian, 488 U.S. at 182,199 . The pertinent section of the federal law provides: "Every person who, under color of any statute, ordinance, regulation, custom, or usage, of any State ... subjects, or causes to be subjected, any citizen of the United States ... to the deprivation of any rights, privileges, or immunities secured by the Constitution and laws, shall be liable . . ." 42 U.S.C. $\S 1983$ (1988). The Fourteenth Amendinent Due Process Clause states that "nor shall any State deprive any person of life, liberty, or property, without due process of law." U.S. CONST. annend XIV, $\S 1$. The Court held that "[i]n this case the under-color-of-law requirement of 42 U.S.C. $\S 1983$ and the state-action requirement of the Fourteenth Amendinent are equivalent." Tarkanian, 488 U.S. at 182 n.4.

40. Tarkanian, 488 U.S. at 194.

41. The University possesses the authority to withdraw from the NCAA and follow its own rules and to work with the NCAA to amend any rules it considers unfair. Id. at 194-95. 
tions, the Court ruled that the University's participation in the formulation of the bylaws did not make the NCAA a state actor. ${ }^{42}$ The Court concluded that the NCAA, as the enforcer of the NCAA's bylaws, is the private representative of its nember institutions, not the state agent of UNLV.3

Because the Supreme Court held that the NCAA was not a state actor, it never reached the inerits of Tarkanian's due process claim. Therefore, the Supreme Court did not analyze whether Tarkanian received due process, or what due process protections, if any, the NCAA should incorporate into its enforcement procedures. Nevertheless, the enormous publicity generated by this case, the recent proposed and enacted state and federal legislation, and the NCAA's legal challenge against these state laws ${ }^{44}$ have kept the due process issue in the limelight, where it will probably remain until the public is satisfied that NCAA enforcenient regulations conform witll due process requirements. Because due process is the standard selected by the groups urging NCAA reform, it is important to examine how due process requirements would apply to the NCAA if it were a state actor.

\section{B. Due Process Requirements}

Due process analysis consists of two parts: first, what rights are classified as "life, liberty, or property," and, second, what process is "due."

42. Id. at 195. The Court also pointed out that even though UNLV may not find alternative responses, such as withdrawing from the NCAA, attractive (as it would want to remain a basketball power), a private monopolist's ability to force its will on a state entity does not transform the private party into a state actor. $I d$ at $198-99 \&$ n.19 (citing Jackson v. Metropolitan Edison Co., 419 U.S. 345, 351-S2 (1974)).

43. Id. at 196. Legal scholars have criticized the rationale underlying the Supreme Court's decision. See, e.g., Kevin M. McKenna, The Tarkanian Decision: The State of College Athletics Is Everything but State Action, 40 DEPAUL L. REV. 459, 494-97 (1991).

44. For a discussion of the NCAA's challenge to Nevada's due process law, see infra subsection $\operatorname{III}(\mathrm{A})(2)$.

45. This step formerly distinguished between "rights" and "privileges." However, courts no longer utilize this distinction because they have determined that due process protection should extend to "privileges" as well as "rights." JOHN E. NOWAK \& RONALD D. ROTUNDA, CONSTITUTIONAL LAW \& 13.5, at 514 (4th ed. 1991); see also PETER L. STRAUSS, AN INTRODUCTION TO ADMINISTRATIVE JUSTICE IN THE UNITED STATES 38 (1989); William Van Alstyne, The Demise of the Right-Privilege Distinction in Constitutional Law, 81 HARV. L. REV. 1439, 1462-63 (1969). But see Rodney A. Smolla, The Reemergence of the Right-Privilege Distinction in Constitutional Law: The Price of Protesting Too Much, 35 STAN. L. REv. 69, 69 (1982).

46. It is difficult to develop a comprehensive list of required procedures as due 
1. What Rights Are Protected Under Due Process? Regardless of how unfair or arbitrary a governmental action is, due process is not required if the government does not deprive an individual of "life, liberty, or property." 47 Because life is deprived in rare instances ${ }^{48}$ and would not apply to NCAA action even if it were a state actor, this Note focuses on the more complex issues raised by liberty and property rights. ${ }^{49}$

Generally, if a state actor deprives an individual of the freedom to engage in "some significant area of human activity"-i.e., liberty-a procedure must exist that examines the basis and the legality of the deprivation. ${ }^{50} \mathrm{~A}$ government action deprives an individual of liberty if it limits the individual's freedom of choice or prevents the exercise of a constitutionally protected right. ${ }^{51}$ Thus if, for example, a government action forecloses an individual from a wide range of employment opportunities, a hearing must be accorded that individual. ${ }^{52}$

Determining whether a government action deprives an individual of property without due process hinges on the question of what constitutes property. ${ }^{53}$ Benefits that do not fall within the traditional real and personal property categories have presented difficulties for the courts. ${ }^{54}$ But the Supreme Court has recognized

process is more amorphous than other legal concepts and must be apphed on a case-by. case basis, with careful attention to the specific situation. "Due process is not a mechanical instrument .... It is a delicate process of adjustment inescapably involving the exercise of judgment by those whom the Constitution entrusted with the unfolding of the process.' " STRAUSS, supra note 45, at 37 n.92 (quoting Joint Anti-Fascist Refugee Comm. v. McGrath, 341 U.S. 123, 163 (1951) (Frankfurter, J., concurring)).

47. NowAK \& RoTUNDA, supra note $45, \S 13.2$, at 491.

48. For example, capital punishment. See id. \& 13.3, at 491-96.

49. This determination of whether liberty and property interests are deprived does not indicate whether there has been a due process violation. Finding interference with liberty and property interests is merely the first step of the due process analysis. Deprivation of liberty and property interests may satisfy judicial scrutiny if the appropriate due process procedures, see infra subsection I(B)(2), lave been followed.

50. NowaK \& RotUNDA, supra note 45, \& 13.4(d), at 509 (citing Henry P. Monaghan, Of "Liberty" and "Property", 62 CORNELl L. REV. 405 (1977)).

51. For example, deprivation occurs if the challenged action inakes certain activitye.g., engaging in a particular business, id. $\$ 13.4$ (d), at 508-09-illegal or impossible. Id. $\S$ 13.4(a), at 497. However, unless prohibited by the Constitution, the government can limit individual freedoin to promote societal interests. Id. $\$ 13.4$ (c), at 505 .

52. Id. $\S 13.4$ (d), at 509; cf. id. ("[I]f an agency ... seeks to revoke the professional status or license of a doctor or lawyer, it inust accord that individual a fair hearing.").

53. Id. \$ 13.5, at 513 .

54. For example, welfare payments or right to public education. Id. $\S 13.5$, at 514 . 
protected property interests in benefits to which an individual can demonstrate entitlement. ${ }^{55}$ To determine if an individual has a "fair claim" to a benefit that has been denied, a court examines local law. If the court finds a property imterest under local law, it then determines if the state utilized fair procedures in denying the benefit. ${ }^{56}$

The Supreme Court illustrated its views on liberty and property rights in two landmark cases. In Board of Regents v. Roth, ${ }^{57}$ the Supreme Court held that a university professor who was not rehired by a state university was not entitled to a hearing or a statenient of reasons for the decision..$^{58}$ The Court examined the nature of the professor's deprivation to determine if his interests were protected by the Fourteenth Amendment. ${ }^{59}$ It found that the university dismissed Roth consistent with state law and without damaging his reputation or preventing him frons securing other eniployment. Because the university had hired Roth for a specified terin, and Roth was not a tenured professor, the Court concluded that he had no right to continued eniployment after the term expired. ${ }^{6}$ Moreover, the Court held that because the university's actions did not damage Roth's reputation, honor, or integrity, or create a stigma that would prevent him from securing other work, Roth was not deprived of a hberty interest protected by the Fourteenth Amendment, ${ }^{61}$ and therefore, he was not entitled to the heightened protection of due process. ${ }^{62}$ Although Roth did not

55. The individual must have already "received the benefit" or "had a previously recognized claim of entitlement." Id.; see also Board of Regents v. Roth, 408 U.S. 564, 576 (1972). However, demonstrating an entitlement merely recognizes an interest in keeping a right, not a requirement that the right must always be preserved. William G. Buss, Due Process in the Enforcement of Amateur Sports Rules, in LAW \& AMATEUR SPORTS 1, 15-16 (Ronald J. Walcukauski ed., 1982).

56. NOWAK \& ROTUNDA, supra note $45, \S 13.5$, at 516 ; see also Cleveland Bd. of Educ. v. Loudermill, 470 U.S. 532, 538-41 (1985); Davis v. Scherer, 468 U.S. 183, 192-93 nn.10-11 (1984).

57. 408 U.S. 564 (1972).

58. Id. at 578-79.

59. Id. at 571. The Court recognized that the liberty interest protected included " 'freedom from bodily restraint" " and " the right of the -individual to contract, to engage in any of the common occupations of life, to acquire useful knowledge, to marry, establish a home and bring up children, ... a and generally to enjoy those privileges long recognized . . . as essential to the orderly pursuit of happiness by free [people]." "Id. at 572 (quoting Meyer v. Nebraska, 262 U.S. 390, 399 (1923)).

60. Id. at 566-68.

61. Id. at 575 .

62. Id. at $573-74$. 
possess a liberty interest in being rehired, the Court nonetheless recognized that " $[t]$ here might be cases in which a State refused to reemploy a person under such circumstances that interests in liberty would be implicated." ${ }^{33}$ For example, a State cannot so damage an employee's reputation as to limit the employee's freedom of choices, ${ }^{64}$ or foreclose other einployment opportunities, without due process. ${ }^{65}$

In addition, the Court ruled that Roth had no property interest in another term of employment since he had no "legitimate claim of entitlement" to it. ${ }^{66}$ Roth's property interest in his employment was limited by the specific terms of his appointment and did not extend to being rehired for another term. ${ }^{67}$

In Perry v. Sindermann, ${ }^{68}$ the companion case to Roth, the Court elaborated on the method for determining which property rights receive due process protection. After four successive oneyear teaching contracts, a public college's board of regents refused to renew a professor's contract and did not provide an official statement of reasons or an opportunity for a hearing. ${ }^{69}$ The professor, Sindermann, claimed that the board's practice of renewing one-year contracts constituted de facto tenure and that the board had deprived him of his due process rights. ${ }^{70}$ The Court referred to Roth and held that since " "property' denotes a broad range of interests that are secured by 'existing rules or understandings," "71 the board of regents inay have created an unwritten "common

63. Id. at 573 .

64. Nevertheless, damage to personal reputation without proof of other harm does not constitute deprivation of "liberty" under the Fourteenth Amendment. See Paul v. Davis, 424 U.S. 693, 708-10 (1976) (stating that damage to a person's reputation is not a per se deprivation of liberty). The individual can recover damages for this injury under traditional tort theory. For a discussion of why this right should be protected by due process, see Henry P. Monaghan, Of "Liberty" and "Property", 62 CoRNELL L. REV. 405, 432-34 (1977).

65. Roth, 408 U.S. at 573-74; see Goss v. Lopez, 419 U.S. 565 (1975) (holding disciplinary action against students without due process a deprivation of liberty if it damages relationships with other students or future education or employment prospects).

66. Roth, 408 U.S. at 577. The Court stated that " $[\mathrm{t}] \mathrm{o}$ have a property interest in a benefit, a person clearly must have more than an abstract need or desire for it. He must have more than a unilateral expectation of it." Id.

67. Id. at 578 .

68. 408 U.S. 593 (1972).

69. Id. at 594-95.

70. Id. at $600-01$.

71. Id. at 601 (citing Roth, 408 U.S. at 577). 
law" agreement giving employees tenure. ${ }^{n}$ The Court concluded that if on remand Sindermann could demonstrate a property interest arising from such "common law" tenure, he would be entitled to a statement of reasons and a hearing. ${ }^{73}$

To receive due process protection, then, an individual must demonstrate either a liberty or a property interest that is deprived by the challenged action. Institutions and individuals under investigation by the NCAA have several hiberty interests at stake. The NCAA can dictate when a member institution must terminate a coach or suspend a student, ${ }^{74}$ and thus may deprive an institution of a liberty interest in freedom of association or freedom of choice. The terminated coach, unlike the professors in the above cases, could claim that the stigma associated with a termination or suspension could prohibit future choices of coaching employment. ${ }^{75}$ Similarly, a student-athlete who has been declared meligible to compete could claim a deprivation of the liberty interest in engaging in a significant human activity or in attempting to pursue a professional sports career. ${ }^{76}$ Again, if indeed there has been a deprivation of an individual's (liere, a coach's or a student's) liberty interest, such individual must be accorded a fair hearing."

NCAA investigations also threaten several protected property interests. For example, NCAA sanctions may deprive an institution of a property interest in the money it would have received from

72. Id. at 602 .

73. Id. at 603. However, a person can be discharged without due process protection if the employment is terminable for any reason under applicable law. NOWAK \& ROTUNDA, supra note $45, \S 13.5$, at 515 (citing Bishop v. Wood, 426 U.S. 341 (1976)).

74. See NCAA MANUAL, supra note 3, arts. 14.13.1, 19.4.2.

75. See Hennessey v. NCAA, 564 F.2d 1136 (5th Cir. 1977) (holding that even though there is no long-term employment contract, coaches have a liberty interest in their occupation); Stanley v. Big Eight Conference, 463 F. Supp. 920 (W.D. Mo. 1978) (ruling that football coach has liberty interest in his good name and reputation because they affect his ability to secure another coaching position). But see Codd v. Velger, 429 U.S. 624 (1977) (determining that an employee is entitled to a hearing only if the employer created and disseminated false and defamatory information about the employee).

76. Behagen v. Intercollegiate Conference of Faculty Representatives, 346 F. Supp. 602, 604 (D. Minn. 1972); JOHN WeIsTART \& CYM H. LOWELl, THE LAW OF SPORTS 24-25 (1979). However, even though some cases emphasize the significance of "an entire line of employment activity," courts have generally been reluctant to find such a liberty interest. Buss, supra note 55, at 13; see, e.g., Colorado Seminary v. NCAA, 417 F. Supp. 885,895 (D. Colo. 1976) (characterizing the college athletic forum as a training gronnd for professional careers but declining to find a liberty interest in speculative professional career).

77. See supra notes $50-52$ and accompanying text. 
television broadcasts of regular season games or appearances in post-season tournaments. ${ }^{78}$ If the NCAA requires an institution to terminate a coach's employment, the coach may claim loss of a property interest in future income. ${ }^{79} \mathrm{~A}$ suspended student-athlete may claim deprivation of a property interest in an athletic scholarship and in the opportunity to obtain a cost-free education or to develop skills necessary for a future professional athletic career. ${ }^{80}$

Because NCAA investigations imperil both liberty and property interests, affected parties would be entitled to due process protection if the NCAA were a state actor. Indeed, as discussed in Part II, proponents of NCAA reform argue that subjects of NCAA investigations should be provided with a high level of due process protection.

2. Determining What Process Is Due. ${ }^{81}$ Although the Fifth and Fourteenth Amendments specify that a person deprived of life, hberty, or property is entitled to due process, they do not define what process is due. The Supreme Court, in Mathews v. Eldridge, ${ }^{82}$ established a balancing test for determining what process is due-a test that transfers certain adversarial procedures to the administrative process. ${ }^{83}$ This subsection provides a framework for analyzing the specific due process requirements that would apply to the NCAA under the proposed and enacted state and federal due process legislation.

78. As a penalty for rules violations, the NCAA may forbid television appearances or participation in post-season toumaments. NCAA MANUAL, supra note 3, arts. 19.4.2.5, 19.4.2(d), (e), (f).

79. However, for NCAA coaches, a property interest in employment is difficult to prove because coaches do not have long-term contracts. In fact, it is common for institutions to fire coaches before their contracts expire if their teams are not winning.

80. A student-athlete could also claim a property interest in education at a particular institution. Ira Berkow, Sports of the Times: $A$ Solution for McRae vs. N.C.A.A., N.Y. TIMES, Dec. 17, 1991, at B13 (student temporarily declared inehgible to play for Syracuse University by the NCAA claimed he was deprived of his right to attend Syracuse for its communications department). Because courts have generally refused to recognize students' property rights in interscholastic athletics, student-athletes should attempt to demonstrate that athletics is more than a component of education. They must prove it is their only chance for a career. Robert G. Riegel, Jr. \& Mark A. Hanley, Comment, Judicial Review of NCAA Decisions: Does the College Athlete Have a Property Interest in Interscholastic Athletics?, 10 STETSON L. REV. 483, 501-02 (1981).

81. For a discussion of whether current NCAA procedures comply with the due process standards discussed in this Section, see infra subsection $\operatorname{II}(B)(2)$.

82. 424 U.S. 319,335 (1976).

83. For the Court's formulation of this test, see infra text accompanying note 101 . 
a. Procedures required by the Due Process Clauses. The Supreme Court has consistently demonstrated its belief that procedures transferred from the adversary process to administrative hearmgs will satisfy the due process requirements of the Fifth and Fourteenth Amendments and will protect an individual from arbitrary governmental action. ${ }^{84}$ For example, Goldberg v. Kelly ${ }^{85}$ extended to administrative proceedings the practice in criminal cases of specifying detailed procedural requirements. ${ }^{86}$ In Goldberg, the Court held that the state could not even temporarily terminate welfare benefits without due process protection. ${ }^{87}$ Although the state conceded that the welfare recipient was entitled to notice and informal commumications with a welfare official, the Court ruled that due process also required an impartial hearing, the right to an attorney, the right to present evidence, the opportunity to cross-exainine, and an opinion explaining the decision. 88

Because of the factual nature of any due process inquiry, there is no definitive hist of required due process elements. ${ }^{89}$ However, Judge Henry Friendly of the Court of Appeals for the Second Circuit developed the following prioritized hist of procedures, taken from criminal trials, ${ }^{90}$ required for a fair hearing, that should be included in any administrative due process clainu:

1. An unbiased tribunal.

2. Notice of the proposed action and the grounds asserted for it.

3. Opportunity to present reasons why the proposed action should not be taken.

4. The right to present evidence, including the right to call witnesses.

5. The right to know opposing evidence.

6. The right to cross-examine witnesses.

7. A decision based exclusively on the evidence presented.

8. Opportunity to be represented by counsel.

84. NOWAK \& ROTUNDA, supra note $45, \S 13.8$, at 524 .

85. 397 U.S. 254 (1970).

86. STRAUSS, supra note 45 , at 40 .

87. 397 U.S. at 264.

88. Id. at $266-71$.

89. STRAUSS, supra note 45 , at 47 .

90. This Note utilizes Judge Friendly's relatively stringent requirements, as opposed to more lenient administrative standards, see, e.g., Goss v. Lopez, 419 U.S. 565, 577-84 (1975), because the state and federal legislatures and the public are calling for strict compliance with due process to safeguard the critical interests at stake. 
9. Requirement that the tribunal prepare a record of the evidence presented.

10. Requirement that the tribunal prepare written findings of fact and reasons for its decision. ${ }^{91}$

Judge Friendly also included requirements for public attendance and judicial review, but questioned their applicability to admimistrative hearings..$^{92}$ The requirement of an unbiased tribunal ${ }^{93}$ prevents the participation of adjudicators who have personal stakes in a case, including monetary or professional interests. ${ }^{94}$ However, the list does not require a separate investigator/prosecutor and adjudicator in administrative proceedings. ${ }^{95}$ In fact, the Supreme Court lias held that it is possible for an administrative law judge to direct the inquiry, present the government's case, and decide the dispute without compromising the duty to be impartial. ${ }^{96}$

b. The Matthews balancing test. In Mathews v. Eldridge, ${ }^{9}$ the Supreme Court devised a balancing test for determining what procedures are required before an individual may be deprived of life, liberty, or property. This case involved a due process claim, based on Goldberg v. Kelly, ${ }^{98}$ that Social Security disability benefits could not be terminated without a pre-termination evidentiary hearing." Stating that "due process is flexible and

91. STRAuSs, supra note 45 , at 47-48 (citing Henry J. Friendly, Some Kind of Hearing, 123 U. PA. L. REv. 1267 (1975)). Although this list is still highly influential and is organized in order of importance, the courts will determine the required procedures on a case-by-case basis. $I \dot{d}$. at 48 .

92. Henry J. Friendly, Some Kind of Hearing, 123 U. PA. L. REv. '1267, 1293-95 (1975). Judge Friendly did not separately list the right to cross-examine witnesses, but discussed it extensively. Id. at 1282-86.

93. Although different cases require different procedures, courts consistently require an impartial and fair process, including a neutral judge. NOWAK \& ROTUNDA, supra note $45, \S 13.8$, at 528 .

94. Id.

95. STRAuSs, supra note 45 , at 48 .

96. Id. at 48 (citing Mathews v. Eldridge, 424 U.S. 319 (1976); Richardson v. Perales, 402 U.S. 389 (1971)); see also Withrow v. Larkin, 421 U.S. 35 (1975); Ronald D. Rotunda, The Combination of Functions in Administrative Actions: An Examination of European Alternatives, 40 FORDHAM L. REV. 101 (1971).

97. 424 U.S. 319 (1976).

98. 397 U.S. 254 (1970); see supra notes 85-88 and accompanying text.

99. Mathews, 424 U.S. at 325. The Secretary of the Social Security Administration (SSA) agreed that continued disability benefits constituted a property interest, but nevertheless contended that the agency's existing procedures satisfied due process requirements. Id. at $332-33$. 
calls for such procedural protection as the particular situation demands," "100 the Court identified the following three factors for determining the requisite procedures:

First, the private interest that will be affected by the official action; second, the risk of an erroneous deprivation of such interest through the procedures used, and the probable value, if any, of additional or substitute procedural safeguards; and finally, the Government's interest, including the function involved and the fiscal and administrative burdens that the additional or substitute procedural requirement would entail. ${ }^{101}$

Applying this balancing test, the Court held that existing Social Security Administration (SSA) procedures satisfied due process requirements. ${ }^{102}$

This balancing test developed by the Supreme Court addresses the "variability of procedural requirements" and "emphasizes that each setting or program invites its own assessment."103 For example, the Court distinguished the outcome in the Mathews case from that in Goldberg. ${ }^{104}$ Accordingly, courts should apply the Mathews test to the operation of the admimstrative program as a whole, rather than focus on the specific facts of a particular case. ${ }^{105}$ Therefore, determining whether NCAA regulations provide due process protection requires an analysis of the NCAA's overall enforcement process, not particular cases.

100. Id. at 334 (quoting Morrissey v. Brewer, 408 U.S. 471, 481 (1972)).

101. Id. at 335. Therefore, the court must balance the "importance of the individual liberty or property interest" and the possibility of reducing erroneous judgments against the increased administrative costs. NowAK \& ROTUNDA, supra note $45, \S 13.8$, at 531.

102. Mathews, 424 U.S. at 349. The Court held that the physically disabled worker's personal interest was less than in other cases as the potential deprivation from terminated benefits would probably be minimal, given possible sources of other income. Id. at 341-42. In addition, the Court ruled that because current SSA procedures were fair and were likely to produce reliable results, a hearing would not add substantial value to the process. Id. at 343-45. Finally, the Court stated that the administrative and societal costs would be substantial. Id. at $347-48$.

103. STRAUSs, supra note 45 , at 45.

104. Mathews, 424 U.S. at 340 . Because terminating welfare benefits pending determination of the claim may deprive the beneficiary of the means to live, the private interest in Goldberg was greater than that in Mathews. Id. In addition, the SSA procedures in Mathews were more reliable and fair than those in Goldberg. Id. at 344-45.

105. See STRAUSS, supra note 45 , at 45 . 


\section{NCAA REgulations AND DUE PROCESS: PAST, PRESENT, AND FUTURE}

Although the NCAA is not bound by the Fourteenth Amendment of the United States Constitution, an evaluation of the necessity of due process reform of the NCAA requires an examination of whether existing NCAA enforcement procedures satisfy constitutional standards. ${ }^{106}$ Section A reviews traditional due process criticisms of the Association by focusing on complaints aired during the 1978 Congressional hearings on the NCAA. Section B discusses current NCAA enforcement regulations ${ }^{107}$ and evaluates whether they satisfy due process requirements. This Section concludes that, although NCAA regulations generally comply with due process, a few deficiencies exist. Section $C$ examines whether recent reforms proposed by the NCAA cure these due process inadequacies. If adopted, these proposals should alleviate the public pressure for more reform.

\section{A. Due Process Issues Raised During the 1978 Congressional Hearings on NCAA Enforcement Procedures}

Congress first considered complaints of NCAA unfairness and lack of due process in 1978 when a House of Representatives subcommittee conducted hearings to address allegations of "unfairness, arbitrariness, inequality, secrecy, and other abuses of excessive power." ${ }^{10 s}$ The subcommittee met on ten occasions to consider testimony from athletic administrators, coaches, student-athletes, professors, attorneys, and NCAA personnel. The problems most frequently cited by witnesses challenging NCAA enforcement procedures fell into three general categories: the investigation of alleged violations, the limited information provided to institutions and staff members under investigation, and the close relationship between the enforcement staff and the Cominittee on Infractions.

106. Because the NCAA is not a state actor, these reforms are not required by law. See supra Section I(A).

107. These procedures are current as of the 1992-1993 academic year. See NCAA MANUAL, supra note 3.

108. NCAA Enforcement Program: Hearings Before the Subcomm. on Oversight and Investigations of the House Comm. on Interstate and Foreign Commerce, 95th Cong., 2d Sess. 2 (1978) [hereinafter 1978 Hearings] (statement of John E. Moss, Subcommittee Chairman). 
The majority of complaints about the investigative process criticized the NCAA's lack of fairness and its misuse of power. A former NCAA enforcement representative testified that a six-week investigation at any school could estabhish at least a technical violation of the complex NCAA rules ${ }^{109}$ and that the NCAA arbitrarily selected schools for investigation. ${ }^{10}$ There were also claims that the NCAA often began investigations into an institution's athletic program or interfered with a coach's einployment opportunities as retaliation for challenging NCAA procedures in court or in public. ${ }^{111}$ Although the mvestigative process is supposed to be a cooperative endeavor between the NCAA and the member institution charged with violations, witnesses repeatedly cited the adversarial nature of the proceedings and the disproportionate power of the NCAA. ${ }^{112}$ In addition, several witnesses presented examples of misconduct by NCAA enforcement staff during investigations, including the threatening and intimidating of witnesses ${ }^{113}$ and the leaking of information to the press before an institution or individual could defend itself at a hearing. ${ }^{114}$ Furthermore, as there was no statute of limitations in the NCAA enforcement regulations, the NCAA could decide to investigate violations that allegedly occurred ten or twenty years prior to the investigation. ${ }^{115}$

109. Id. at 27-28 (testimony of J. Brent Clark, Special Assistant, Oversight and Investigations Subcommittee of the House Committee on Interstate and Foreign Commerce).

110. The witness provided examples of how "politics and balance sheets seemed to dictate" the NCAA's handling of cases. For example, the NCAA called off an investigation of serious allegations involving illegal representation by an agent of several athletes at a large college, but fully pursued an investigation into minor technical violations at a small institution. Id. at 11.

111. Id. at 8-11; see also id. at 195 (testimony of Charles Butler, Bowling Green University, and former assistant football coach at Michigan State University).

112. See, e.g., id. at 5 (testimony of J. Brent Clark); id. at 128 (testimony of Erwin C. Ward, former counsel to Mississippi State University in proceedings before the NCAA); id. at 219 (testimony of Dr. Frederick D. Williams, Professor of History and Adjunct Professor of Military Science and Member of the Select Committee, Michigan State University).

113. Id. at 218 (testimony of Dr. Frederick D. Willians); see also id. at 137-38 (testimony of Bob Tyler, Head Football Coach, Mississippi State University).

114. Id. at 225-26 (testimony of Dr. Frederick D. Williams); see also id. at 5 (testimony of J. Brent Clark); id. at 573-74 (testimony of Lana Tyree, attorney, Oklahoma City, Oklahoma).

115. Id. at 57 (testimony of J. Brent Clark). 
Consistent with the complaint that the NCAA did not provide adequate due process, ${ }^{116}$ witnesses testified that the NCAA failed to furnish the institutions with the information necessary to conduct a defense. ${ }^{17}$ For example, after mitiating an official investigation, the NCAA failed to notify the institution of the procedures that would be followed during the investigation. ${ }^{118}$ Additionally, on several occasions the NCAA failed to provide the institution or mdividual staff members with information consistent with the cooperative nature underlying discovery principles, ${ }^{119}$ including the nature of the charges. ${ }^{120}$ Furthermore, the institutions and individual staff members were denied the opportunity to confront their accusers and to cross-examine witnesses. ${ }^{121}$ Witnesses also criticized the unavailability of complete transcripts of interviews and hearings. ${ }^{122}$

Another recurring complaint was that the NCAA did not provide institutions or individuals with unbiased investigations. ${ }^{123}$ For example, witnesses alleged that the hearings began with a presumption of guilt that placed the burden of proof on the charged party, rather than on the NCAA. ${ }^{124}$ In addition, the close working relationship between the enforcement staff (investigator and prosecutor) and the Committee on Infractions (adjudicator) precluded fair consideration of the evidence. ${ }^{125}$ Finally, as the NCAA Council oversees the investigative process, witnesses beheved that they could not receive an unbiased tribunal, even on appeal. ${ }^{126}$

116. Id. at 219 (testimony of Dr. Frederick D. Williams).

117. Id. at 873-75 (statement of John E. Moss).

118. Id. at 809-10 (testimony of Dr. Donald H. Baepler, Chancellor, University of Nevada System); id. at 820-21 (testimony of K. Michael Leavitt, Counsel, University of Nevada System).

119. Id. at 824 (testimony of K. Michael Leavitt); id. at 259 (testimony of Dr. Stanley B. Kegler, Vice President, University of Minnesota); id. at 6-7 (testimony of J. Brent Clark).

120. Id. at 815 (testimony of Jerry Tarkanian, Head Basketball Coach, UNLV); id. at 573 (testimony of Lana Tyree).

121. Id. at 260 (testimony of Dr. Stanley B. Kegler); id. at 810 (testimony of Dr. Donald H. Baepler).

122. Id. at $826,864-65$ (testimony of $\mathrm{K}$. Michael Leavitt); id. at 546 (testimony of Lana Tyree).

123. Id. at 874 (statement of John E. Moss).

124. See, e.g., id. at 511 (testimony of Mickey Holmes, Commissioner, Missouri Valley Conference).

125. Id. at 7 (testimony of J. Brent Clark); id. at 474-75, 501-02 (testimony of John A. Fuzak, former president of the NCAA).

126. Id. at 223 (testimony of Dr. Jacob A. Hoefer, Professor of Animal Husbandry 
Unsurprisingly, NCAA staff members defended the enforcement procedures in existence and denied several of the allegations. They insisted that relations between the enforcement staff and the Committee on Infractions were professional and that the Committee based its decisions on the facts, not on the staff's recommendations. ${ }^{127}$ These NCAA witnesses also asserted that investigations and penalties were not arbitrary and that the enforcement staff had the burden of proving the institution's guilt. ${ }^{128}$ In addition, since investigating the cases that prompted the charges raised at the hearings, the NCAA instituted reforms that alleviated some of these complaints. ${ }^{129}$ For example, interviewees are now allowed legal counsel, ${ }^{130}$ the Committee "generally observes" a four-year statute of limitations, ${ }^{131}$ and enforceinent procedures are designed to ensure a cooperative effort between NCAA enforcement staff and member institutions. ${ }^{132}$ Despite such reforms, the NCAA defended its refusal to provide verbatim transcripts of hearings to protect the confidentiality of the witnesses and the investigation. $^{133}$

After the liearings, the subcommittee issued a report recommending a variety of reforms to NCAA enforcement procedures. ${ }^{134}$ Because the subcommittee recognized that the NCAA

and Associate Director, Michigan Agricultural Experiment Station, Michigan State University); id. at 547, 574-75 (testimony of Lana Tyree).

127. Id. at 1068-69 (testimony of Arthur R. Reynolds, former chairman of the Committee on Infractions, NCAA); id. at 899 (testimony of J. Neils Thompson, President, NCAA).

128. Id. at 1063-68 (testimony of Arthur R. Reynolds).

129. Id. at 1059-63 (testimony of Arthur R. Reynolds); id. at 894 (testimony of $\mathrm{J}$. Neils Thompson); id. at 1376-77 (testimony of William B. Hunt, Assistant Executive Director, Enforcement Program, NCAA).

130. Id. at 895 (testimony of J. Neils Thompson); see NCAA MANUAL, supra note 3, arts. 32.3.5, 32.6.4, 32.8.3.

131. I978 Hearings, supra note 108, at 896 (testimony of J. Neils Thompson); see NCAA MANUAL, supra note 3, art. 32.5.2. However, the statute of limitations provision does not apply to allegations affecting the eligibility of a current student-athlete, "indicat[ing] a pattern of willful violations . . . which began before but continued into the four-year period." In addition, the statute of limitations is one year for cases involving "a blatant disregard for the Association's fundamental ... regulations or ... an effort to conceal the occurrence of the violation." Id.

132. 1978 Hearings, supra note 108, at 900 (testimony of J. Neils Thompson); id. at 1376 (testimony of William B. Hunt).

133. Id. at 897-98 (testimony of J. Neils Thompson).

134. See generally H.R. REP. No. 69, 95th Cong., 2d Sess. (1978) [heremafter H.R. REP. No. 69]. 
should impose its own reforms, the report suggested that the NCAA form a "blue ribbon panel" to evaluate the recommendations generated by the hearings. ${ }^{135}$ Such recommendations included increasing the information available to the institutions and individuals under investigation, ${ }^{136}$ separating the functions of the enforcennent staff from those of the Committee of Infractions, ${ }^{137}$ and implementing a formal statute of limitations on initiating and concluding investigations. ${ }^{138}$

In January 1979, the NCAA Convention rejected two proposals to overhaul the NCAA's enforcement system and to conduct a year-long evaluation of this reform plan. ${ }^{139}$ Although both proposals reflected recommendations suggested during the congressional hearings, they were independent of the subcommittee's report. ${ }^{140}$ Because many of the recommendations were already incorporated into NCAA enforcement procedures, the Convention approved measures to " 'clarify' that these are existing practices." 141 In addition, the Convention instituted a formal "four-year statute of limitations on investigations."142 Despite these measures, Congress was unappeased; an additional congressional hearing in July 1979 inade clear that the NCAA would be closely scrutinized to ensure that it complied with the subcommittee recommendations. ${ }^{143}$

135. Id. at 58; see also Nancy Scannell, NCAA Threatened with Federal Law, WASH. PosT, Jan. 9, 1979, at D1. However, the "minority called the year-long investigation 'a waste of time." "Id.

136. H.R. REP. No. 69, supra note 134 , at $25-26,41$ (recommendations that all parties should have access to information used at hearings, enforcement staff should inform parties of all accusations and when their interests may be adversely affected, and the NCAA should provide access to complete transcripts of hearings).

137. Id. at 26, 40-41, 51 (recommendations that the Committee on Infractions should not supervise the enforcement staff's investigation or prepare the infractions report and that the enforcement staff should not determine penalties).

138. Id. at 26-67.

139. Nancy Scannell, NCAA Rejects Reform Plan, WASH. PoST, Jan. 10, 1979, at C1. Burton Brody, a law professor at the University of Denver, and ten colleagues sponsored the proposal, which recommended "alter[ing] the relationship between the NCAA investigator-prosecutor (enforcentent staff) and the judge (infractions committee)." Stephen Horn, the president of Long Beach State University, sponsored the proposal for a yearlong review of the Brody plan to study its legal repercussions. Id.

140. Id.

141. Id.

142. Id.

143. NCAA Action Scrutinized, WASH. POST, July 13, 1979, at C3. Issues unresolved at that time included access to hearing transcripts and sharing of information between the NCAA and the institution under investigation. Id. 
Although the NCAA did not adopt all of the Congressional recommendations, it did institute soine reforms in response to the hearings and the challenges to its procedures. Nevertheless, these reforms have not prevented continuing criticisms of NCAA enforcement procedures. The next Section analyzes current NCAA procedures in hight of the problems identified in the 1978 hearings and considers whether these procedures currently comply with traditional due process requirements.

\section{B. Current NCAA Enforcement Regulations}

Since the 1978 Congressional hearings, the NCAA has instituted gradual reforms to eliminate many of the sources of the due process complaints. This Section reviews current NCAA enforcement regulations and dernonstrates that, although they comply with inost basic due process standards, they do not satisfy all of the requirements. However, by eliminating or merely explaining these due process deficiencies, the NCAA could reduce the external pressure for reform by alleviating the public's perception that NCAA enforcement regulations are unfair and arbitrary and fail to provide due process protection. ${ }^{144}$

1. NCAA Enforcement Regulations. Article 19 of the NCAA Manual establishes the duties of the committee charged with administering the Association's enforcement program, the procedures to be followed, and the penalties to be imposed. The six-meinber Committee on Infractions, appointed by the NCAA Council, is responsible for admimistering the NCAA enforcement program. ${ }^{145}$ The Committee on Infractions may impose disciplinary or corrective actions without seeking further approval, except in cases of inajor violations, suspensions, or terminations of menbership. ${ }^{146}$ Responsibilities of the Committee include: con-

144. See, e.g., Alison Muscatine, NCAA Urged to Modify Inquiries; Special Committee

- Proposes New Steps, WASH. POST, Oct. 29, 1991, at E1; Intercollegiate Sports: Hearings Before the Subcomm. on Commerce, Consumer Protection, and Competitiveness of the House Comm. on Energy and Commerce, 102d Cong., 1st Sess. 58-61 (1991) [hereinafter 1991 Hearings] (statement of James E. King, Florida State Representative); id. at 52-54 (statement of Don Yaeger, author of UNDUE PROCESS (1991)); id. at 31-37 (statement of Jerry Tarkanian, Head Basketball Coach, UNLV). But see id. at 12-16 (statement of David P. Roselle, President, University of Delaware, and former president of the University of Kentucky).

145. NCAA MANUAL, supra note 3, art. 19.1.

146. Id. art. 19.1.2 (stating that "cases involving major violations ... shall be subject 
sidering complaints that member institutions violated NCAA academic or athletic standards; determining the facts connected with such alleged violation and deciding whether such violations occurred; imposing appropriate penalties; and formulating and revising a statement of the Committee's operating procedures. ${ }^{147} \mathrm{Be}$ fore any penalties are imposed on a member institution, the Committee must provide the institution with notice of the alleged violations, "the opportunity to appear before the committee and the opportunity to appeal the committee's findings of major violations or penalties." ${ }^{\prime 148}$

The degree of notice provided to a member institution depends on the severity of the alleged violations. ${ }^{149}$ Any member institution under investigation receives "[n]otice of any specific charges against it and the facts upon which such charges are based."150 A member institution charged with secondary violations is afforded the opportunity to respond to the charges by writing to the assistant executive director for enforcement. ${ }^{151}$ For charges of major violations, a member institution may appear before the Committee on Infractions to challenge the allegations with sup- . porting evidence. ${ }^{152}$

The NCAA enforcement regulations also distinguish between secondary violations and major violations in imposing penalties. The assistant executive director for enforcement and the Committee on Infractions may impose penalties from a hist of suggested penalties, based on the severity of the violations, the number of violations, and other mitigating factors. ${ }^{153}$ However, certain mini-

to review by the Council on appeal").

147. Id. art. 19.1.3.

148. Id. art. 19.2.1.

149. There are two types of violations. A secondary violation is an isolated event which provides "limited recruiting or competitive advantage." All other violations are major violations, especially if they provide "an extensive recruiting or competitive advantage." In addition, the assistant executive director for enforcement may reclassify repeated mcidents of minor violations as major violations. Id. art. 19.02.2.

150. Id. art. 19.3.

151. Id. art. 19,3.2 (the institution may appear before the Committee on Infractions on appeal).

152. Id. art. 19.3.1.

153. There are six suggested penalties for secondary violations, including terminating the recruitment of a prospect or the eligibility of a student-athlete; forfeiting athletic contests; prohibiting a coach from off-campus recruitment for a year; imposing a fine ranging from $\$ 500$ to $\$ 5,000$; reducing a maximum of $20 \%$ of financial aid awards; and recertifying that the institution's policies conform to NCAA regulations. Id. art. 19.4.1. Suggested 
mum penalties exist for major violations. ${ }^{154}$ In addition, the Committee must impose the "death penalty" if it finds that an institution has committed a major violation within five years from the start of a previous penalty for a major violation. ${ }^{155}$ Other than a written appeal to the Council division steering committee representing the institution's division or the Committee on Infractions, ${ }^{156}$ there is no vehicle for review of the Committee's findings unless new evidence surfaces or prejudicial procedural error is shown. ${ }^{157}$

Article 32 of the NCAA Manual specifies the details of the NCAA's enforcement policies and procedures. The article covers preliminary review of information, ${ }^{158}$ investigative procedures, ${ }^{159}$

penalties for major violations are more numerous and include: probation; ineligibility for post-season toumaments and meets; denial of television coverage; reduction in financial aid awards; requirement to "show cause" why penalties should not be imposed if the institution does not take the appropriate disciplinary action against the involved personnel; and the return of proceeds gained from competitions involving an ineligible athlete. Id. art. 19.4.2.1.

154. Id. art. 19.4.2.2. These required penalties include: two years of probation; "[t]he elimination of all expense-paid recruiting visits to the institution in the involved sport for one recruiting year;" denial of off-campus recruiting activities in the involved sport; termination or reassignment of all institutional staff members who knowingly engaged in or condoned a major violation; one year of sanctions denying participation in post-season events and television broadcasts; and recertification that the institution's current procedures conform to NCAA regulations. Under extenuating circunistances, the Committee does not have to impose these penalties. Id.

155. Id. art. 19.4.2.3. The "death penalty" prohibits coaching or competition in the latest involved sport and eliminates all new grants-im-aid awards for that sport for two years. There are also forfeitures of the institution's voting rights and committee positions in the NCAA for four years. Id.

156. An institution may appeal, in writing, the violations found and/or the penalties imposed on behalf of itself, a staff nember, or a student-athlete. Id. art. 19.5.

157. Id. art. 19.4.2.8.1.

158. The enforcement staff investigates and reviews information concerning possible violations to determine whether there are enough facts to warrant further inquiry and whether the alleged violation is major or secondary. The staff must also provide the institution with notification of the preliminary investigation, the relevant procedures that will be followed, and a status report every six months. Id. art. 32.2.

159. This provision details the procedures for conducting interviews of institutional staff members and student-athletes. If a witness may divulge information that could be detrimental to his interest, the enforcenent representative must inform the individual of the purpose of the interview and the witness may be represented by counsel. The interview reports are confidential but may be reviewed by the witnesses to ensure accuracy. An institutional representative may attend any portion of the interviews that directly relate to the institution, but will not receive a copy of the interview report. Id. art. 32.3.

In 1991, the Committee on Infractions, in response to complaints of contradictory information and a lack of reliable records, amended article 32.3.8 to instruct enforcement 
processing information, ${ }^{160}$ the official inquiry, ${ }^{161}$ hearings before the Committee on Infractions, ${ }^{162}$ notification of Committee action, ${ }^{163}$ and appeals. ${ }^{164}$ After allegations are made against an individual or member institution, the Committee on Infractions controls the entire process, from the initial information-gathering through the hearing and penalty assessment. ${ }^{165}$ Moreover, under

representatives to record interviews when possible and to permit handwritten notes by all involved parties. Id. art. 32.3.8. The mechanical recordings will be treated the same as written reports and will therefore remain confidential and unavailable to individuals or institutions requesting information on the case. See id. art. 32.3.9.

The enforcement staff is evaluating the results to determine whether taping interviews will inhibit witnesses. Enforcement Staff Continues to Tape Interviews in Cases, NCAA NEws, July 17, 1991, at 1, 20; see also University of Nev. v. Tarkanian, 594 P.2d 1159, 1161 (Nev. 1979) (claiming that the only record of witness interviews was derived froin oral reports of staff investigators' recollections of interviews).

160. If an institution initiates corrective action in response to a violation, the Committee on Infractions or the assistant director for enforcement may decide not to impose further penalties. If the corrective action is insufficient, the enforcement staff must notify the institution of additional penalties for secondary violations or file an official inquiry for major violations. Furthermore, the Committee considers self-disclosure by the institution as a mitigating factor in determining penalties. NCAA MANUAL, supra note 3 , art. 32.4 .

161. If the enforcement staff decides that allegations warrant investigation, the staff must provide the institution with a letter of official inquiry that explains the scope of the inquiry, describes the allegations, identifies the involved individuals, and requests disclosure of all relevant information. At the time the official inquiry is filed, the staff must suggest a date for the institution to meet with the Committee on Infractions and provide notice of the hearing procedures. In addition, the staff must prepare a case suinmary that the institution may review before the hearing. Id. art. 32.5.

162. An institution has the opportunity to appear before the Committee to present facts in a major case or to appeal a decision in a secondary violation case. The Committee expects requested individuals to appear in person, with legal counsel if desired. This hearing is comprised of a case suminary, opening statements by the institution and the enforcement staff, staff presentation, institution presentation, and closing statements by the institution and the enforcement staff. The Committee may exclude irrelevant, immaterial, or repetitious information and may question witnesses. The hearing will be tape recorded but the institution may not receive a copy of the tape or a transcript of the hearing. After the hearing, the Committee rules on each alleged violation and assesses any penalties. $I d$. art. 32.6.

163. The Committee must promptly provide the institution with an infractions report explaining its findings and any penalties. After the institution receives the report, it may be released to the media, with names of individuals deleted. Id. art. 32.7.

164. An institution or individual staff meinber niay appeal to the appropriate steering division of the NCAA Council within fifteen days of receipt of the Committee's report. The Council will grant the appeal if the finding is contrary to the evidence, a violation of NCAA rules did not occur, or a procedural error affected the reliability of information. Id. art. 32.8. The appeal may be in person or in writing. The Council's decision is final and is not subject to further review. Id. art. 32.9 .

165. This organizational structure is the source of the critics' largest due process com- 
the regulations, charged parties have no right to cross-examine witnesses or to receive the interview reports and transcripts. ${ }^{166}$

2. Due Process Analysis of Current NCAA Enforcement Regulations. This subsection examines current NCAA enforceinent regulations against factors typically required for due process in adininistrative proceedings. First, Judge Friendly's hist of procedures required for fair administrative proceedings is apphed to NCAA regulations to identify specific due process standards that have been satisfied. ${ }^{167}$ Then, in areas where due process standards have not been satisfied, the Mathews balancing test ${ }^{168}$ will be applied to determine if the NCAA should provide the missing due process protection. Although NCAA regulations satisfy six important due process requirements, the NCAA could comply with three additional requirements with minimal administrative costs. Two due process requirements, however, would be too costly to administer and would not be worth inipleinenting.

a. NCAA enforcement regulations satisfy six of Judge Friendly's due process requirements. Current NCAA enforceinent regulations satisfy six of the due process requirenents identified by Judge Friendly: ${ }^{169}$ notice of the proposed action and the grounds asserted for it; an opportunity to present reasons why the proposed action should not be taken; the right to know opposing evidence; a decision based exclusively on the evidence presented; an opportunity to be represented by counsel; and a requirement that the tribunal prepare written findings of fact and reasons for the decision.

plaint-the lack of a neutral adjudicator. See supra text accompanying notes 123-26.

166. See NCAA MANUAL, supra note 3, arts. 32.3.9, 32.6.5, 32.6.5.8. The NCAA defends this policy, stating that the hearings are not meant to mirror a court case and that the NCAA does not have the authority to subpoena witnesses. Muscatine, supra note 144 , at E1.

167. Friendly, supra note 92, at 1279-94; see supra text accompanying note 91 . The elements identified by Judge Friendly as necessary for a fair hearing are relevant in determining the necessary elements of fair NCAA investigative procedures.

168. Mathews v. Eldridge, 424 U.S. 319, 335 (1976); see supra text accompanying note 101.

169. See supra text accompanying note 91. Because Judge Friendly questioned the suitability of adding to litigation by requiring judicial review, this requirement will not be discussed. See Friendly, supra note 92, at 1294-95. 
NCAA enforcement regulations satisfy the requirement of providing institutions with notice of the proposed action and the grounds asserted. ${ }^{170}$ The enforcement staff must notify an institution of preliminary investigations that are likely to require further inquiry and must provide status reports every six months. ${ }^{171}$ Additionally, if the enforcement staff determines that a full investigation is necessary, it must submit to the institution a Letter of Official Inquiry that identifies the allegations, factual basis for the charges, and individuals charged. ${ }^{172}$

Further, NCAA regulations grant institutions the opportunity to present reasons why the proposed action should not be taken. ${ }^{173}$ An institution may respond to secondary violations in writing and to major violations or appeals of secondary penalties at a hearing before the Committee on Infractions; ${ }^{174}$ and it may appeal major violations to the NCAA Council. ${ }^{175}$

Although NCAA regulations do not incorporate traditional discovery rules, they provide institutions with the right to know opposing evidence ${ }^{176}$ by requiring the disclosure of all facts that corroborate or refute the allegations. ${ }^{177}$ In addition, an institution receives a copy of the summary statement of the case and has the opportumity to "review in the NCAA national office those memorandums and documents upon which the enforcement staff will rely."

Furthermore, only evidence presented at hearings before the Committee on Infractions has an impact on the resolutions of NCAA investigative proceedings. ${ }^{179}$ Committee findings are based exclusively on the credible and persuasive evidence presented at

170. See Friendly, supra note 92, at 1280-81.

171. NCAA MANUAL, supra note 3, art. 32.2.2.4.

172. Id. arts. 32.5.1, 19.3.

173. See Friendly, supra note 92 , at 1281.

174. NCAA MANUAL, supra note 3, arts. 19.3, 32.6.2.

175. Id. art. 32.9.

176. See Friendly, supra note 92 , at 1283 .

177. NCAA MANUAL, supra note 3, art. 32.5.8.

178. Id. art. 32.5.10. Nevertheless, it is difficult to effectively review the information and prepare a defense without possessing copies of the opposing information. Additionally, institutions not located near the NCAA's national headquarters in Kansas will likely have to make several expensive trips there.

179. See Friendly, supra note 92, at 1287. 
such hearings. ${ }^{180}$ If the Committee requests additional information, both sides may be present. ${ }^{181}$

Moreover, NCAA regulations provide, for most involved parties, the opportunity to be represented by counsel. ${ }^{182}$ All parties questioned during an interview that may "develop information detrimental to the [individuals'] interests" may be represented by legal counsel. ${ }^{183}$ In addition, mdividuals testifying at the request of the Committee may bring legal counsel to the hearing. ${ }^{184}$ An institution is also permitted to have legal counsel in attendance at the hearing. ${ }^{185}$

NCAA regulations also require that the tribunal prepare written findings of fact and reasons for its decisions: ${ }^{186}$ Before any public announcenient, the Committee on Infractions or the enforcement staff must prepare an Infractions Report. This report "contain[s] a consolidated statement of all penalties, corrective actions, requirenents, and other conditions and obligations of membership imposed upon a member institution found $\mathrm{m}$ violation of NCAA legislation." 187

b. Balancing test analysis of Judge Friendly's due process requirements not satisfied by NCAA enforccment regulations. Current NCAA regulations do not afford due process protection in five of the areas identified by Judge Friendly. These missing elements are: an unbiased tribunal; the right to call witnesses; the right to cross-examine witnesses; a requirenient that the tribunal prepare a record of the evidence presented; and an open hearing.

First, the investigative procedures and the close working relationship between the Committee on Infractions and the enforce-

180. NCAA MANUAL, supra note 3, art. 32.6.6.2. The Committee conducts its deliberations in private, without the presence of the enforcement staff. Id. art. 32.6.6.

181. Id. art. 32.6.6.1. This requirement prevents the Committee from requesting additional information or clarification from the enforcement staff without the institution or individual being able to defend itself.

182. See Friendly, supra note 92, at 1287-91.

183. NCAA MANUAL, supra note 3, art. 32.3.5.

184. Id. art. 32.6.4.1.

185. Id. art. 32.6.4.2.

186. See Friendly, supra note 92, at 1291-92.

187. NCAA MANUAL, supra note 3, art. 32.7.1. Moreover, after an appeal, the Coinmittee or the NCAA Council must submit an Expanded Infractions Report containing similar information. Id. art. 32.8.5. 
ment staff do not appear to provide institutions and charged individuals with an unbiased tribunal. ${ }^{188}$ The Committee on Infractions administers the NCAA enforcement program. ${ }^{189}$ Its responsibilities imclude considering initial complaints filed against a member, conducting hearings for major violations, weighing the evidence related to alleged violations, imposing penalties for secondary and major violations, and hearing appeals of secondary violations. ${ }^{190}$ The enforcement staff operates under the guidance of the Committee on Infractions. ${ }^{191}$ Its duties mclude gathering basic infornation, handling minor violations through correspondence, selecting matters for full investigation, and consulting with the Committee when procedural questions arise. ${ }^{192}$ The enforcement staff is also responsible for conducting the investigation and presenting the evidence during the hearing before the Committee. ${ }^{193}$ Moreover, the enforcement staff may prepare the Infractions Report at the request of the Committee. ${ }^{194}$

The Committee on Infractions, responsible for weighing the evidence and imposing penalties, supervises the enforcement staff that gathers the evidence and presents the NCAA's case at the hearing. This close working relationship between the decisioninaker and the investigator/prosecutor gives the mipression that the outcome is decided before the hearing occurs-that is, it appears unlikely that an unbiased tribunal weighs the testimony of both sides. Indeed, as all members of the Committee on Infractions and enforcement staff are affiliated with the NCAA, investigative procedures should provide more "procedural formality" than "if the decisionmaker were not a member."195

The Mathews balancing test ${ }^{196}$ is helpful in deciding whether the NCAA should adopt reforns that create a less biased tribunal. Because current procedures create a public perception of impropri-

188. See Friendly, supra note 92 , at $1279-80$.

189. NCAA MANUAL, supra note 3, art. 19.1.

190. Id. art. 19.1.3.

191. Id. art. 32.2.2.

192. Id. art. 32.2.2.1.

193. Id. arts. $32.3,32.6 .5$.

194. Id. art. 32.7.1.

195. See Friendly, supra note 92, at 1279.

196. See supra text accompanying note 101. In general, the test weighs "the importance of the individual liberty or property interest" and the possibility of reducing erroneous judgments against the increased admimistrative costs. NOWAK \& ROTUNDA, supra note $45, \S 13.8$, at 531 . 
ety, especially if the decision favors the NCAA, the institution or individual under investigation appears to be at risk of losing the liberty and property interests at stake in the case. ${ }^{197}$ Separating the investigator and the adjudicator should dispel the appearance of collaboration and should convince the public that erroneous judgments are less likely to occur because the decision is based on evidence presented, rather than on predetermined opinions. Moreover, unbiased tribunals are less likely to deliver erroneous judgments.

It is true that the administration of an unbiased tribunal would be coinplicated and would require substantial administrative and personnel changes. ${ }^{198}$ Nevertheless, the most prominent complaints against the NCAA have been the inherent unfairness and arbitrariness of the enforcement process. ${ }^{199}$ Individuals and institutions frustrated by the outcome of an NCAA investigation, often blame the "unfairness" of the process, rather than acknowledge violations of NCAA rules. Because it is likely that challenges to NCAA regulations would dramatically decrease if it appeared that subjects under investigations were treated fairly, the NCAA should incur the increased administrative costs and create an unbiased tribunal. 200

In addition to falling short of the requirements for an unbiased tribunal, NCAA enforcement regulations fail to ineet several infornational due. process requirements. ${ }^{201}$ For example, NCAA regulations do not provide institutions with the right to cross-examine the enforceinent staff's witnesses. ${ }^{202}$ Similarly, NCAA regulations do not grant the right to present coinplete evidence since

197. Examples are the institution's freedom of association and right to revenues, the individual's right to employment, and the student-athlete's right to participate in athletic competitions. For a more detailed discussion on the institution's, individual's, and studentathlete's hiberty and property rights, see supra subsection $\mathrm{I}(\mathrm{B})(1)$.

198. For example, the NCAA would have to identify independent personnel with knowledge of administrative hearings and NCAA rules. In addition, to ensure that this independent staff has inininal contact with the enforcement staff or Committee on Infractions, the NCAA would need to reorganize the infractions staff and reassign functions.

199. See supra Section II(A).

200. Moreover, because public perception, not legal requirements, spearheads the push for NCAA reform, solving the most prominent complaint should be worth the extra effort and cost.

201. Lack of information has also been a recurring due process coinplaint. See supra Section $\mathrm{II}(\mathrm{A})$.

202. See Friendly, supra note 92, at 1283-86; see also NCAA MANUAL, supra note 3, art. 32.6.5. 
they do not include the right to call all relevant witnesses. ${ }^{203} \mathrm{Al}$ though institutions have the right to present evidence ${ }^{204}$ and to request the presence of its representatives during the hearing before the Committee on Infractions, ${ }^{205}$ the institutions' witnesses are limited to officials, legal counsel, and those individuals identified by the enforceinent staff. ${ }^{206}$ Moreover, parties under investigation do not have adequate access to the tribunal's record of the evidence presented. ${ }^{207}$ The Committee on Infractions's record of the hearing-a tape recording-is the only permissible verbatim record. Although parties nay review the relevant sections of the tape, they inay not receive or make a copy of the tape or a verbatim transcript of the hearing. ${ }^{203}$ Finally, NCAA hearings are not currently open to the public and therefore do not satisfy the due process requirement of an open hearing. ${ }^{209}$

Consideration of these four requirements under the Mathews balancing test indicates that although reforms in these areas would improve the fairness of the investigative procedures, only two of these requirements are worth the administrative costs. Having the opportunity to call all relevant witnesses, to review the complete record of the hearing, to cross-examine witnesses, and to participate in an open hearing would provide parties under investigation with more complete information than do current procedures. This access to relevant information would lead to inore effective defenses against the allegations, either at the initial hearing or on appeal; consequently, the parties' property and liberty interests would be better protected. Although complying with these requirements would not guarantee a favorable outcoine for the parties under investigation or eliminate erroneous suits, ${ }^{210}$ the administrative costs of providing an opportunity to call all revevant witnesses and

203. See Friendly, supra note 92 , at 1282.

204. NCAA MANUAL, supra note 3, art. 32.6.5.

205. Id. art. 32.6.2.

206. Id. art. 32.6.4.2. Denying this right to call witnesses should be limited to instances where there is a "substantial . . interest in preserving the overall integrity of institutions and programs .... and there is a substantial chance that the individual may be more interested in disruption than in proving his case." Friendly, supra note 92, at 1282 n.80.

207. See Friendly, supra note 92, at 1291-92.

208. NCAA MANUAL, supra note 3 , art. 32.6.5.8.

209. See Friendly, supra note 92, at 1293-94. For an evaluation of proposed reforms that would provide public hearings, see infra Section II(C).

210. Althoúgh the public may perceive these factors to affect the results, other variables, such as the strength of a case, could have a greater impact on the outcome. 
complete hearing transcripts would likely be modest. Accordingly, the NCAA should reform its current procedures to provide parties under investigation with the rights to call relevant witnesses and to access and review adequately the complete hearmg record; these procedures will increase the fairness of the investigative proceedings without creating substantial administrative problems.

Allowing parties to cross-examine witnesses, however, would be inore difficult, because the NCAA does not have the power to subpoena witnesses. ${ }^{211}$ Furthermore, because cross-examinations tend to be utilized as a delay tactic, courts have been willing to dispense with the requirement in many cases. ${ }^{212}$ Providing open hearings is also unfeasible. ${ }^{213}$ Although allowing public attendance could protect the liberty and property interests of charged institutions and individuals and reduce the risk of erroneous judginents, ${ }^{214}$ the administrative costs are too great to warrant implementation. For exainple, NCAA facilities are not equipped to handle the number of people that would try to attend hearings, especially when they involve well-known and controversial parties, sucli as Jerry Tarkanian and UNLV. Accommodating this public interest and implementing procedures similar to those utilized by courts during ligh-profile trials would require enlarging the NCAA staff. NCAA investigations often involve high-profile sports programs that are frequently featured in newspaper and television stories, capturing the public's attention. This disproportionate amount of publicity surrounding NCAA proceedings enhances the negative effects of open hearings, distinguishing thein from most other administrative proceedings. ${ }^{215}$

211. Witnesses, who currently testify voluntarily, might be unwilling to appear at a hearing if they have to be subjected to the unpleasantness of cross-examinations.

212. Friendly, supra note 92 , at 1284-86. Other disadvantages to requiring cross-examinations are the reluctance of witnesses to testify, "undue exacerbation," and "polarization" of continuing relationships. Situations where courts did not require cross-examinations include prisoner cases, discipline of students, and eviction proceedings. Id. at 1286.

213. For reaction to proposed NCAA reforms that would provide for open hearings, see infra notes $232,237-38$ and accompanying text.

214. Open hearings could result in NCAA proceedings that appear to be fairer than current hearings. Public attendance at trials theoretically provides due process by fostering confidence in the proceeding, assuring the accuracy of the evidence, and ensuring that officials conduct fair proceedings. Friendly, supra note 92 , at 1293 n.132.

215. These negative effects include intimidating some witnesses, providing incentives to other witnesses for "hamming it up," attaching greater stigma to parties ultimately found innocent, and providing too much publicity for the NCAA's "dirty laundry." 
Based on Judge Friendly's list and the Mathews balancing test, the NCAA should adopt reforms to provide charged parties with an unbiased tribunal, the riglit to call witnesses, and the opportunity to review a complete record of the hearing. It is not currently feasible, however, for the NCAA to guarantee the right to cross-examination or to provide open hearings. Because the deficiencies in these areas drive the push for reform, the NCAA sliould adopt the reforms that are feasible and should clearly explain to the public, the member institutions, coaches, and studentathletes why it should not have to satisfy the remaining due process requirements. The next Section discusses recent proposals for NCAA reform and analyzes whether they cure the due process deficiencies identified in this Section.

\section{Evaluation of the NCAA's Proposed Reforms}

As discussed in the previous section, due process problems remam despite the NCAA's efforts to reform its enforcement procedures since the 1978 congressional hearings. In response to legislative action by Congress and several states, ${ }^{216}$ the NCAA formed a special committee in 1991 to analyze its enforcement provisions. ${ }^{217}$ The committee, headed by Rex Lee, president of Brighain Young University and a former U.S. Sohicitor General, focused on the implications of implementing due process requirements. ${ }^{218}$ As the eleven-member committee combined former judges, including former United States Supreme Court Chief Justice Warren Burger, with academic and athletic administrators, it could develop recommendations to address due process concerns while it retained the NCAA's regulatory position. ${ }^{219}$

216. See discussion infra Part III.

217. NCAA Executive Director Richard D. Schultz proposed the creation of the special committee to ensure that the enforcement process is "fair, effective, timely and consistent." Committee Releases Enforcement-Review Report, NCAA NEws, Nov. 4, 1991, at 12 .

218. Danny Robbins, Enforcement Power of NCAA to Be Topic for State Legislature, L.A. TIMES, May 12, 1991, at C3. According to Lee, "the group's three objectives were to keep the NCAA's enforcement effort fair while maintaining its effectiveness, to provide a uniform structure that would be the same in all states, and to assure that the system would be based on cooperation between the institution and the NCAA." Enforcement Panel Issues Report, NCAA NEws, Nov. 4, 1991, at 1.

219. The other nine members of the committee were Reuben V. Anderson, former Mississippi State Supreme Court Judge; Charles Cavagnaro, Director of Athletics, Memphis State University, and a member of the NCAA Council; Benjamin R. Civiletti, for- 
On October 28, 1991, the special committee recommended eleven dramatic changes to the NCAA enforcement process. ${ }^{220}$ Although some of the proposals addressed due process concerns, others made suggestions that would generally improve NCAA enforcement procedures. For example, the most innovative proposal called for the creation of a summary disposition process to settle cases quickly through cooperative action between the NCAA and the institution under investigation. ${ }^{221}$ Under this plan, the two sides would be able to share information and agree upon a statement of the facts, negotiate findings of violations, and propose penalties. ${ }^{22}$ By curtailing the number of full hearings, this proposal would reduce the effect of the "biased tribunals." 223 Another important proposal provided that if the NCAA and the institution were unable to negotiate a resolution during the summary-disposition process, an independent hearing officer would review the facts and propose penalties. ${ }^{224}$ This change would create an unbiased tribunal and would alleviate public criticism that the Committee on Infractions is both prosecutor and judge. 225 The special committee stressed this goal, stating that the Committee on Infrac-

mer U.S. Attorney General; Charles W. Ehrhardt, Professor of Law and Faculty Athletics Representative, Florida State University; Becky R. French, University Counsel, North Carolina State University; Charles Renfrew, Vice President, Legal, Chevron Corp., former federal district judge, and former Deputy U.S. Attorney General; William M. Sangster, Director of International Programs and Faculty Athletics Representative, Georgia Institute of Technology, and a member of the NCAA Council; Philip W. Tone, former federal district and federal circuit court judge; and Paul R. Verkuil, President, College of William and Mary, and a former dean of Tulane Law School. Committee Releases EnforcementReview Report, supra note 217, at 12.

220. Michael Janofsky, N.C.A.A.'s Panel Recommends Updated Rules for Investigations, N.Y. TIMES, Oct. 29, 1991, at B9.

221. The objective behind this recommendation was to reduce the time devoted to an investigation, thereby lessening the amount of adverse publicity and more efficiently utilizing institution and NCAA resources. Committee Releases Enforcement-Review Report, supra note 217 , at 13 .

222. Id. This proposal would foster a cooperative environment and a proceeding that is expected to last no longer than three or four months. Id.

223. See supra text accompanying notes 188-200.

224. Committee Releases Enforcement-Review Report, supra note 217, at 13. The committee recommended that the hearing officer "be a former Federal judge, state court judge, or other eminent legal authority or person of stature whose imtegrity and impartiality are beyond question." Id. In addition, the NCAA Administrative Committee should select and supervise a pool of officers who would receive training on NCAA regulations and procedures. $I d$.

225. Id. This recommendation should also improve the public's perception of and confidence in the fairness of the enforcement process. $I d$. 
tions would serve as the supervisor of the investigation and the summary disposition process, not as "the hearing panel to determine the facts in a case."

The special committee also recommended several proposals to improve the availability of information to institutions and the public. ${ }^{27}$ It endorsed supplying transcripts or tape recordings of NCAA hearings and interviews to all appropriate involved parties; $; 28$ providing greater access to information so as to allow parties under investigation to present better defenses and obtain fairer hearings; and opening hearings to the public so as to enable the NCAA to communicate to the public the reasons behind decisions, thereby lessening the public perception that the NCAA imposes penalties arbitrarily. ${ }^{229}$ The other five proposals were also aimed at guaranteeing fair procedures and improving the efficiency and cooperative nature of the proceedings. ${ }^{230}$

The NCAA Council has agreed to sponsor legislation at the 1993 NCAA Convention consistent with nine of the eleven special committee recommendations. ${ }^{231}$ However, the Council declined to support legislation on utilizing independent hearing officers and conducting open hearings. ${ }^{232}$ Although these two proposals will

226. Id. at 14. The other duties of the Committee on Infractions would be: reviewing penalty agreements; considering appeals; assessing penalties based on the hearing officer's recommendation; and monitoring the enforcement process. Id.

227. Muscatine, supra note 144 , at E1.

228. Committee Releases Enforcement-Review Report, supra note 217, at 13. The special committee believed that these changes would foster a cooperative environment and enhance the reliability of the evidence. Id.

229. To improve further the public's perception of NCAA enforcement practices, the special committee proposed expanding the reporting of infractions cases. Id. at 14.

230. The remaining recommendations included: ensuring personal visits by enforcement staff to deliver the preliminary notice of inquiry; providing a special appeal council of representatives of NCAA member nistitutions and conferences; adopting a formal conflict-of-niterest policy; preparing compilations of previous committee decisions; and studying the structure and procedures of the enforcement staff. Id. at 12-14. The provision on open hearings was the only recommendation on which the special committee was closely divided. Id. at 13.

231. Council to Sponsor Institutional Certification Plan, NCAA NEws, Aug. 19, 1992, at 18 . Because the menbers must receive notice of proposed changes at least ninety days prior to consideration, a vote could not have occurred at the 1992 Convention and therefore had to wait until the 1993 Convention. Janofsky, supra note 220, at B9.

232. Council to Sponsor Institutional Certification Plan, supra note 231, at 18. Nevertheless, the Council agreed to sponsor an amendment that would add iidependent individuals to the Committee on Infractions. The proposed amendment specifies that the Committee's size would increase by two and that the two new members would be selected from legal authorities outside the NCAA. Council Minutes, Meeting August 5-7, 1992, 
not be approved at the 1993 Convention, their eventual implementation remains possible. ${ }^{233}$ These reforms would reduce the due process criticisms of NCAA regulations, yet their implementation may not be easy; for example, although it would be important to achieve the goals ${ }^{234}$ of the summary disposition process, it may be difficult to coordinate the activities of the NCAA staff and the institution to conduct a joint imvestigation. ${ }^{235}$

Unsurprisingly, the two proposals that the Council chose not to sponsor would be the most difficult to implement. First, it would be difficult and costly to locate and train qualified independent hearing officers. Moreover, because the "independent" officer would be supervised by NCAA officials and would work with enforcement staff on numerous cases, the same close relationship that currently exists between the enforcement staff and the Cominittee on Infractions would perhaps be extended to include the "independent" officer. Second, opening the hearings to the public may not be worth the costs. ${ }^{236}$ In fact, given the dissension within the NCAA on whether the proposal would improve or impede the proceedings, it is unclear whether this proposal will ever be adopted. ${ }^{237}$ Besides, other special committee proposals satisfy the goal of "mak[ing] the process more positive and understandable to those involved and the general public."238 Nevertheless, to im-

NCAA NEws, Sept. 14, 1992, at 11. Although this recommendation recognizes the need for independent oversight of the NCAA enforcement process, it is unlikely that two out of eight independent committee members will convince the public and the NCAA membership that the tribunal is unbiased.

233. The NCAA Council has agreed to continue reviewing these two issues. Council to Sponsor Institutional Certification Plan, supra note 231, at 18.

234. The main objectives are to shorten the timeframe of an investigation and to reduce the amount of adverse publicity. Committee Releases Enforcement-Review Report, supra note 217 , at 13 .

235. While a cooperative endeavor is more efficient, the interests of the NCAA and the institution under investigation are inherently different. In addition, individuals implicated by the violations will have other interests at stake. A better procedure might be to conduct independent investigations with full discovery rights and joint interviews of witnesses.

236. See supra notes $213-15$ and accompanying text. Most courts do not require open hearings in administrative proceedings. Friendly, supra note 92, at 1293-94.

237. Open Hearings Face an Uncertain Future, NCAA NEws, June 24, 1992, at 18. For example, while D. Alan Williams, faculty representative at the University of Virginia and chair of the Committee on Infractions, beheves that open hearings would "wreak havoc" on the proceedings and would limit the candor of those testifying, Rex E. Lee, president of Brigham Young University and chair of the special committee, argues that the gain in public confidence resulting from open hearings would be worth the cost. Id.

238. Committee Releases Enforcement-Review Report, supra note 217, at 12. These 
prove the public's opinion of the fairness of the NCAA's enforcement procedures, the NCAA slould explain clearly, in a variety of media sources, a decision not to iniplement these two proposals.

By adopting at its 1993 Convention legislation that implements nine of the special committee's recommended proposals, the NCAA should improve the fairness of its enforcement procedures and the public's impression of the fairness of the NCAA. The proposals addressed most of the concerns discussed in subsection II(B)(2). Because the NCAA does not have subpoena power, the special committee did not recommend allowing the accused party to cross-examine witnesses. ${ }^{239}$ At the same time, many of the other proposed reforms, sucli as the summary disposition process, go beyond traditional due process requirements in attempting to inIprove the openness of the hearings and the public's perception of the NCAA. ${ }^{240}$

\section{Who Should RULE COllegiate Athletics?}

Although NCAA regulations and the proposed ainendments to the regulations generally satisfy the legal requirements of due process, several states and Congress have initiated legislative action in response to the public's perception that the NCAA's enforce-

proposals include providing personal notice of the initial inquiry, access to taped interviews and hearing transcripts, and public reports. Id.

239. Muscatine, supra note 144 , at E1. Because the NCAA lacks subpoena power, it is unable to "perfectly duplicate 'due process' as it is guaranteed under the Constitution." Id. This rationale could also explain the special committee's decision not to provide parties under investigation with an opportunity to call all relevant witnesses. Nevertheless, unlike allowing cross-examinations, permitting parties under investigation to call relevant witnesses would not necessarily be adversarial or unpleasant; moreover, it would be worth the extra administrative costs. See supra notes 210-12 and accompanying text.

240. Not surprisingly, none of the proposed reforms specifically addressed concerns relating to student-athletes directly, such as eligibility rules. In general, courts do not find property or liberty interests at stake for student-athletes. See Buss, supra note 55, at 16; Richard Staton, Recent Cases Concerning the Rights of Student Athletes, 10 J.C. \& U.L. 209, 215-16 (1983-84). This result may be due to the courts' perceptions that avoiding high burdens to the schools greatly outweighs the slight interest at stake. Buss, supra note 55, at 17-18. If cases develop that cause the public to decide that student-athletes are not being treated fairly, the NCAA may need to adopt appropriate reforms. Perhaps public opinion led to the recent reversals of ineligibihity determinations involving athletes fron Syracuse University and the University of Texas. See William C. Rhoden, N.C.A.A. Restores McRae at Syracuse, N.Y. TIMES, Dec. 20, 1991, at B13; Cambridge Is Allowed to Play for Texas, N.Y. TIMES, Jan. 26, 1992, at B8. The issue of student-athletes' rights is far fron settled. Kimberly D. Kolback, Property Rights: Athletes Await the Call from the Referee of the Courtroom, 2 ENT. \& SPORTS L.J. 219, 241 (1985). 
ment procedures do not afford due process to investigated parties. This Part examines these legislative efforts and concludes that the NCAA, not state or federal legislatures, should initiate due process reform. Section A delineates the various state bills and laws and discusses the recent lawsuit brought by the NCAA that questions the constitutionality of Nevada's due process law. Section B examines the proposed federal legislation. Section $C$ concludes by arguing that the NCAA is the appropriate organization to oversee its own reform.

\section{A. State Legislation}

Recently, twelve states have introduced or passed into law legislation that would require the NCAA to afford due process to institutions located within state boundaries. ${ }^{241}$ Not coincidentally, major state universities in at least five of these states have experienced first-hand the rigors and publicity of an extensive NCAA investigation. ${ }^{242}$ Although all of these bills share the same ultimate goal, ${ }^{243}$ their specific due process provisions differ. This Section compares the bills and discusses the NCAA's recent constitutional challenge to the Nevada statute.

1. Comparison of State Provisions. The twelve bills and laws fall into three general groups. ${ }^{244}$ The bills introduced in Iowa, ${ }^{245}$ Nebraska, $^{246}$ Rhode Island, ${ }^{247}$ and Soutll Carolina ${ }^{248}$

241. In California, Iowa, Kansas, Minnesota, Mississippi, New York, Rhode Island, and South Carolina, bills have been introduced and are pending further action by the legislature or governor. The bills in California, Iowa, Kansas, Minnesota, and Mississippi have missed deadlines and have failed to move out of committee but may be reintroduced next session. Florida, Illinois, Nebraska, and Nevada have enacted due process laws. State Due Process Legislation, NCAA NEWS, May 27, 1992, at 3 [hereinafter 1992 Legislation Chart].

242. Florida, Illinois, Kansas, Nevada, and South Carolina. Danny Robbins, Enforcement Power of NCAA to Be Topic for State Legislature, L.A. TIMES, May 12, 1991, at C3.

243. See, e.g., Illinois Due-Process Bill Is Signed, NCAA NEws, Sept. 16, 1991, at 2. The states want to " "ensur[e] that any procedures used to determine violations of [NCAA] regulations are fair to the university, the athletes, the coaches and the students." "Id. (quoting Jim Edgar, governor of Illinois).

244. State Due Process Legislation, NCAA NEws, July 31, 1991, at 10-11 [hereinafter 1991 Legislation Chart]. One common characteristic of all of the due process legislation is a requirement that all penalties imposed be subject to judicial review. Id.

245. H.B. 450, 71st Gen. Assembly, 2d Reg. Sess. (1992). The House Committee on Judiciary and Law Enforcement recommended against passage and the bill died in com- 
contain the fewest number of specific requirements. Each of these bills stipulates that NCAA enforcement proceedings must coinply with the due process guaranteed by the state's laws and constitution and that penalties inconsistent with the legislation may not be imposed. In addition, the Iowa, Nebraska, and South Carohina bills create a cause of action for damages, costs, and attorney's fees. ${ }^{249}$

The law enacted in Nevada ${ }^{250}$ and the bills pending in California, ${ }^{251}$ Minnesota, ${ }^{252}$ and New York ${ }^{253}$ specify the procedural requireinents the NCAA must provide to schools under investigation, such as an "impartial decision-maker," the right to legal counsel, a record of the proceedings and "no ex parte communications."254 In addition, the NCAA must provide notice ${ }^{255}$ and the right to confront witnesses and evidence; ${ }^{256}$ the NCAA must bear the burden of proving its case by a preponderance of the evidence; ${ }^{257}$ and any imposed penalties must be consistent with the

mittee in 1992. 1992 Legislation Chart, supra note 241.

246. The Nebraska Collegiate Athletic Association Procedures Act, NEB. REv. STAT. $\$ \S 85-1201$ to -1210 (Supp. 1990), was approved by the governor on February 1, 1990. After stating that the NCAA is a private monopolist and exerts great power over the member institutions, the law declares that:

[e]very stage and facet of all proceedings of a collegiate athletic association, college, or university that may result in the imposition of a penalty for violation of such association's rule or legislation shall comply with due process of law as guaranteed by the Constitution of Nebraska and the laws of Nebraska.

Id. $\S \S 85-1202,-1203$.

247. H.B. 8916, Gen. Assembly, Reg. Sess. (1992). This bill was introduced in February 1992 and is still under consideration by the legislature. 1992 Legislation Chart, supra note 241.

248. South Carolina Collegiate Athletic Association Procedures Act, S.B. 16, 109 Gen. Assembly, Statewide Sess. (1992). The legislation is pending in the Senate.

249. 1991 Legislation Chart, supra note 244.

250. NEv. Rev. Stat. ANN. $\S \S 398.155-255$ (Michie 1991).

251. Gen. Assembly, 1991-92 Reg. Sess. (1992). The bill died in January 1992 when the Senate failed to meet the deadline for its passage. 1992 Legislation Chart, supra note 241.

252. S.B. 1565,77 th Leg., 1992 Reg. Sess. (1992). The bill never got out of committee and died when the 1992 legislature adjourned. 1992 Legislation Chart, supra note 241.

253. S.B. 6020, 214th Gen. Assembly, 2d Reg. Sess. (1992). The bill is in committee. 1992 Legislation Chart, supra note 241.

254. 1991 Legislation Chart, supra note 244.

255. The notice must specify the time, place and nature of the hearing; the procedural rules; and the alleged violations and supporting evidence. $I d$.

256. This right includes: exchanging evidence thirty days before the hearing; applying "[s]tate laws of privilege"; requiring written statements to be signed under oath; and permitting objections to the evidence. Id.

257. Id. 
legislation and must be im proportion to the violations found. ${ }^{258}$ Moreover, the statutes in this group establish a private riglit of action for damages and injunctive relief. ${ }^{259}$

The laws passed in Florida ${ }^{260}$ and Illinois ${ }^{261}$ and the bills pending in Kansas ${ }^{262}$ and Mississippi ${ }^{263}$ specify the greatest number of due process requirements. ${ }^{264}$ Provisions in these laws stipulate that the NCAA must open the hearings to the public, provide notice of the hearings to the institution and individuals charged, ${ }^{265}$ furnisl a complete transcript of the hearings, ${ }^{266}$ explam the findings $\mathrm{m}$ writing, ${ }^{267}$ and provide full discovery. ${ }^{268}$ In addition, all evidence and penalties must be consistent witl the standards specified in the legislation. ${ }^{269}$ Moreover, the legislation specify that the

258. Id.

259. Damages include lost income, attorney's fees, and costs. Id.

260. Collegiate Athletic Association Compliance Enforcement Procedures Act, FLA. STAT. ANN. \$\$ 240.5339-.5349 (West Supp. 1992).

261. Collegiate Athletic Association Compliance Enforcement Procedures Act, ILL. ANN. STAT. ch. 144, paras. 2901-2913 (Smith-Hurd 1992).

262. KS S.B. 234, 74th Legis., 2d Sess. (1991). The bill passed the Senate but died in committee in the House. 1992 Legislation Chart, supra note 241. Because the NCAA headquarters are located in Kansas, the Kansas act differs from the Illinois and Florida laws by extending protection to all NCAA enforcement proceedings, including investigations of institutions located outside Kansas. KS S.B. $234 \$ 3$.

Since the bill died in committee, proposed amendments have drastically shifted the focus of the legislation from due process concerns to the structure of the NCAA penalties. See Proposed Amendinents to KS S.B. 234. These amendments may be in response to the NCAA's high-level lobbying efforts and the NCAA special committee's recommendations. Adam Teicher, Bill Limiting NCAA's Power Dies in Kansas House, KaNSAS CITY STAR, Mar. 13, 1992, at D6.

263. S.B. 2301, 107th Legis. (1992). This bill was introduced January 21, 1992, but failed to meet the committee deadline. 1992 Legislation Chart, supra note 241.

264. 1991 Legislation Chart, supra note 244. To guarantee the applicability of due process, the Florida and Illinois laws declare that the "[c]ollegiate athletics associations engage in 'state action." " However, these acts do not apply to investigations into acadeinic qualifications. Instead of mentioning "state action," the Kansas bill stipulates that investigations must comply with state and federal due process. Id. The Mississippi bill highlights the state's involvement in collegiate athletics and calls for enlarged due process protection. S.B. $2301 \S 2(\mathrm{~h})$, (n).

265. The notice inust state the specific charges and the time and date of the learing. 1991 Legislation Chart, supra note 244; S.B. 2301 \& 4(3).

266. 1991 Legislation Chart, supra note 244; S.B. $2301 \& 4(10)$. The Illinois law does not require a record of the proceedings.

267. The NCAA must prove a violation by "clear and convincing" evidence. 1991 Legislation Chart, supra note 244; S.B. $2301 \S 4(5)$.

268. 1991 Legislation Chart, supra note 244; S.B. $2301 \S 4(6)$.

269. Penalties must also be in proportion to the violations found. 1991 Legislation Chart, supra note 244; S.B. $2301 \S 5(1)$, (2). 
hearing must occur within six months of the initial notification, ${ }^{270}$ that state civil rules of evidence apply, and that damages include lost income, costs, and attorney's fees. ${ }^{271}$ These acts also protect member institutions from retaliatory action by the NCAA by stating that the Association may not terminate meinbership because of enactment of the legislation. ${ }^{27}$

\section{The NCAA's Constitutional Challenge to the Nevada Legis-} lation. Recently, the NCAA won a case that challenged the constitutionality of Nevada's due process law. ${ }^{273}$ The NCAA challenged the Nevada law because it was the first due process statute to affect an NCAA investigation. ${ }^{274}$ The NCAA filed suit after the Nevada law-which requires several procedures that are not included in current NCAA regulations ${ }^{275}$-impeded a four-year NCAA investigation of the recruitment of high school basketball star Lloyd Daniels. ${ }^{276}$ The district court held that the Nevada

270. This time limit is extended to nine months if the institution raises the violation. The Florida law has nine-month and one-year statutes of limitations. 1991 Legislation Chart, supra note 244. The Mississippi bill has one-year and eighteen-month statutes of limitations. S.B. $2301 \& 4($ a).

271. The Kansas act also states that the NCAA could lose its tax-exempt status. 1991 Legislation Chart, supra note 244; S.B. 2301 \& 9.

272. The legislation also forbids waivers of any provisions of the acts as a condition of NCAA membership. However, the Illinois law permits any party under investigation to waive rights. 1991 Legislation Chart, supra note 244; S.B. 2301 \& 8(3).

273. NCAA v. Miller, 795 F. Supp. 1476 (D. Nev. 1992). This unprecedented case is the first time the NCAA has sued a state and only the third time the Association has introduced legal action. Danny Robbins, NCAA Fights Back, Challenges Nevada, L.A. TIMES, Nov. 13, 1991, at C1. The original defendants in the suit were Bob Miller, the governor of Nevada; Jerry Tarkanian, UNLV's head basketball coach; Tim Grguirch, UNLV's assistant basketball coach; Rob Ganulin, a former UNLV assistant basketball coach; and Shelly Fischer, a former academic adviser for UNLV's basketball team. The UNLV staff members were named in the suit because their lawyers notified the NCAA that a current investigation must comply with the Nevada law. Id. Subsequent to the initial filing, a district court judge dismissed Governor Miller from the suit and the University System of Nevada decided to uitervene without choosing sides. Judge Dismisses Gov. Miller in NCAA's Challenge of Nevada Law, NCAA NEws, Jan. 22, 1992, at 2.

274. Judge Rules for NCAA in Neyada Case, NCAA NEws, June 10, 1992, at 1.

275. Id. For example, the Nevada law specifies that the NCAA must afford individuals the right to confront all witnesses and evidence. However, NCAA regulations do not provide an opportunity to cross-examine witnesses. Id.; see also supra text accompanying notes $201-09$.

276. Danny Robbins \& Elhott Almond, NCAA Stuck in Nevada, L.A. TIMES, Nov. 13,1991 , at $\mathrm{C} 1$. The NCAA was unable to proceed with the case without risking violations of the Nevada law and further legal action from UNLV. For example, the Association had not even held a prehearing conference because it could be classified as a proceeding under the Nevada law, thereby requiring the NCAA to provide the procedures 
statute was unconstitutional on two grounds and therefore "invalid and unenforceable."2n

First, the court held that the Nevada law violated the Commerce Clause of the United States Constitution. ${ }^{278}$ Noting that the NCAA conducts seventy-six annual championships involving teams and individuals throughout the country, that the NCAA receives hundreds of millions of dollars from interstate television broadcasts of its events, and that recruiting of prospective student-athletes generally occurs on a nationwide basis, the court concluded that the "national scope of the NCAA's activities are sufficient to establish the requisite interstate involvement under the Commerce Clause."279 Because the statute does not discriminate against interstate commerce on its face, the court balanced the state's interest in the legislation against the burden on interstate conmerce. ${ }^{280}$ The court held that the extraterritorial effect of the statute, by inpairing the NCAA's ability to uniformly enforce its regulations and to provide for equal competition among its members, outweighed Nevada's legitnnate interests in enacting the legislation. ${ }^{281}$

The court also held that the Nevada law violated the Contract Clause of the United States Constitution ${ }^{22}$ by substantially impairing the NCAA's contractual relationship with UNLV. ${ }^{283}$ Citing the NCAA's primary purpose of conducting intercollegiate athletic events "on a level and fair playing field," the court ruled that if all members did not follow the same rules, the NCAA's effectiveness would be curtailed. ${ }^{284}$ Nevada, moreover, was unable to prove that the inpairment of the NCAA's contract was necessary or reasonable..$^{285}$

established by the act. Id.

277. Miller, 795 F. Supp. at 1488. The court did not reach the NCAA's two remaining constitutional claims: that the statute violates the NCAA's and its meunbers' First Amendment right of association, and that the statute is vague and overbroad in violation of the Fourteenth Amendment. Id. at 1479, 1488.

278. U.S. CONST. art. I, § 8, cl. 3.

279. Miller, 795 F. Supp. at 1482.

280. Id. at 1483 .

281. Id. at 1485. Nevada's interests included protecting its citizens and in-state institutions froin unfair hearings that are inconsistent with due process. Id. at 1483.

282. U.S. CONST. art. I, $\S 10$.

283. Miller, 795 F. Supp. at 1488.

284. Id at 1486. The judge held that, by changing the enforcement regulations for Nevada institutions, the state law "allow[ed] Nevada institutions to gain an unfair competitive advantage over other members." Id. at 1487.

285. Id at 1487-88. The law was not reasonable because, rather than protecting soci- 
Although at this time, the NCAA can proceed with its investigation of Lloyd Daniels and UNLV, the NCAA's fight against state due process legislation is far from settled. UNLV's Coach Tarkanian has indicated that he will appeal the district court's decision, ${ }^{286}$ and NCAA Executive Director Richard Schultz has stated that he beheves the case will eventually reach the Supreme Court. ${ }^{287}$ In any event, this decision only affects the Nevada law. If the NCAA, wishes to challenge other due process statutes, it must battle each state law individually. ${ }^{288}$

\section{B. Federal Legislation}

It is widely recognized that state legislation, in addition to raising these constitutional issues, could lead to fifty versions of due process requirements, even though the intent of each bill is identical. ${ }^{289}$ A consistent standard for NCAA enforceinent regulations requires federal legislation. Indeed, Representative Ed Towns (D-NY) has recently introduced a federal bill, the "Coach and Athlete's Bill of Rights," in the House of Representatives. ${ }^{200}$ This bill declares that because the NCAA has member institutions in all fifty states that nust travel across state limes to compete against each other, the NCAA engages in interstate commerce. ${ }^{291}$ The bill would require the NCAA to provide general due process protection to any coach, player, or institution associated with the NCAA against whoin it would take action. ${ }^{292}$ To ensure comphance with due process, the bill holds that as a legislative matter, the NCAA is a state actor when NCAA action leads to "the final or decisive act of suspending or reprimanding a coach, player, or

ety, it targeted a narrow interest and it was not necessary because member institutions can amend NCAA regulations. Id. at 1488.

286. Judge Rules for NCAA in Nevada Case, supra note 274, at 1.

287. Open Hearings Face an Uncertain Future, NCAA NEWS, June 24, 1991, at 28. Moreover, both Tarkanian and the NCAA previously demonstrated their willingness to pursue legal battles through appellate review to the Supreme Court. See NCAA v. Tarkanian, 488 U.S. 179 (1988).

288. Judge Rules for NCAA in Nevada Case, supra note 274, at 1.

289. See, e.g., 1991 Hearings, supra note 144, at 60 (statement of James E. King, Florida State Representative, and sponsor of Florida's due process legislation).

290. H.R. 2157, 102d Cong., 1st Sess. (1991).

291. H.R. $2157 \S 2$. Other interstate commerce activities include broadcasting events across the fifty states and "generat[ing] approximately $\$ 1,000,000,000$ in interstate commerce each year." Id.

292. Id. \& 3 . 
institution." ${ }^{293}$ It would require the NCAA to establish enforcement regulations consistent with due process within ninety days after adoption of the act. ${ }^{294}$ The bill would also provide for a study by the Secretary of Commerce on "the impact of NCAA sanctions upon the telecommunications and commercial activities of intercollegiate sporting events and the revenue loss caused by such sanctions." ${ }^{295}$ On June 19, 1991, the House Subcommittee on Commerce, Consumer Protection; and Coinpetitiveness conducted a hearing to evaluate NCAA enforcement procedures and NCAA compliance with due process. ${ }^{296}$ The subcommittee heard testimony from eight individuals with differing views on NCAA procedures, including two head basketball coaches, a university president, two sponsors of state due process legislation, and three individuals familiar with evaluating collegiate athletics. ${ }^{297}$ The majority of individuals testifying urged the committee to utilize federal legislation to encourage the NCAA to adopt due process protections that would be consistent across state lines. ${ }^{298}$ On the other hand, a few witnesses urged the subcommittee to let the NCAA handle reforms internally. ${ }^{299}$ Currently, the conclusions of the subcommittee and the outcome of the federal legislation renuain unknown.

293. Id. $\S 4$.

294. Id. § 3(b).

295. Id. § 5. This report must be submitted to Congress within six months of the enactment of the legislation. Id.

296. 1991 Hearings, supra note 144, at 2 (opening statement of Cardiss Collins, Subcommittee Chairman). Representative Collins also announced that future hearings would consider the allocation of NCAA revenues, "the treatment of women's athletics, [and] . . . preserving the academic integrity of the student athlete." Id.

297. The witnesses were: Creed C. Black, president of the Knight Foundation; Burton Brody, Professor of Law, University of Denver, Dale Brown, Head Basketball Coach, Louisiana State University; Hon. James E. King, Member, Florida House of Representatives, and sponsor of Florida due process bill; David P. Roselle, President, University of Delaware, and former President, University of Kentucky; Jerry Tarkanian, Head Basketball Coach, UNLV; Hon. Wint Winter, Jr., Member, Kansas State Senate, and a sponsor of the Kansas due process bill; and Don Yaeger, author of UNDUE PROCESS (1991). Id. at III.

298. See, e.g., id. at 55 (testimony of Wint Winter); id. at 53-54 (testimony of Don Yaeger); id. at 59-60 (testimony of Janies E. King).

299. See id. at 38-40 (testimony of Dale Brown); id. (testimony of David P. Roselle) (stating that he formd NCAA procedures fair and suggesting that the committee should focus on the role of collegiate athletics in post-secondary education). 


\section{The NCAA Should Rule Itself}

As demonstrated previously, current NCAA enforcement regulations comply with most due process requirements. ${ }^{300}$ Moreover, the reforms proposed by the NCAA special committee, if adopted by the membership, would meet an additional three requirements. ${ }^{301}$ The right to cross-examine witnesses and the right to call all relevant witnesses are the only due process requirements that would not be satisfied. ${ }^{302}$ The NCAA should clearly explain to the public why it cannot provide investigated parties with these rights-and, if any of the other proposed reforms are not adopted at the 1993 NCAA Convention, the NCAA should explain why it cannot provide such reforms-e.g., the reforms would be too costly to implement.

Richard D. Schultz, Executive Director of the NCAA, has recognized that public pressure is driving the movement for reforming NCAA enforcement regulations and that the NCAA must assume an active role. ${ }^{303} \mathrm{He}$ has cited the congressional hearings and federal and state legislative actions as indications that controversy still exists as to whether NCAA enforcement procedures are fair and whether they provide due process to charged parties. ${ }^{304}$

Given the inconsistencies that will arise from individual state bills and the threat of constitutional challenges by the NCAA, state legislation is not the appropriate ineans of solving the problem. ${ }^{305}$ Moreover, state legislation may jeopardize the status of the affected schools' meinbership in the NCAA if they are unable to coinply with NCAA regulations. ${ }^{306}$ Finally, if the NCAA adopts the recent recommendations of the special committee, it is

300. The requirements satisfied by current regulations are: notice of the proposed action and the grounds asserted; an opportunity to present reasons why the proposed action should not be taken; the right to know opposing evidence; a decision based exclusively on the evidence presented; an opportunity to be represented by counsel; and a written report prepared by the tribunal stating the findings of fact and the reasons for its decisions. See supra subsection II(B)(2)(a).

301. The requirements that would be met are: an unbiased tribunal; the right to call witnesses; the requirement that the tribunal prepare a record of the evidence presented; and an open hearing. See supra notes 220-30 and accompanying text.

302. See supra note 239 and accompanying text.

303. P. David Pickle, Pressures Could Shape NCAA's Future, Schultz Tells Convention, NCAA NEws, Jan. 8, 1992, at 1.

304. Id.

305. In addition, because conferences usually consist of member institutions from different states, differences could arise within the same conference.

306. State Laws Might Lead to NCAA Expulsion, L.A. TIMES, Feb. 20, 1991, at C2. 
likely that most due process complaints will be rendered moot. In that event, states may suspend their considerations of due process bills $^{307}$ and repeal due process legislation. ${ }^{303}$

If the NCAA attack on the Nevada law and potential challenges to other state laws succeed, federal legislation may be the only means left to mandate due process standards. However, it is not clear that federal legislation is even necessary. Despite criticisms that the NCAA has not voluntarily instituted reforms, ${ }^{309}$ the NCAA has consistently, since the 1978 congressional hearings, adopted measures designed to improve the fairness of its enforcement procedures. The motivation behind these reforms is irrelevant. What matters is that the NCAA has responded to and continues to respond to the outside pressures by implementing due process reforms. The recent special committee's report demonstrates that the NCAA recognizes the importance of public perception. ${ }^{310}$ In addition, according to the president of the Knight Commission on Intercollegiate Athletics, a 22-member panel that conducted an eighteen-month study on the governing structure of collegiate athletics and issued a well-received comprehensive report in 1991, "'[t]lhere is a window open now" to imstitute reforms. These recent developments emphasize that the NCAA is trying to change its image and to comply with its member institutions' and the public's expectations of fairness. It is now up to the membership to decide whether to approve these reforms.

307. In fact, in six of the twelve states that have introduced such legislation, the bills have died in committee during the 1992 Legislative Session. See supra subsection III(A)(1). These delays have occurred as a result of the NCAA's willingness to implement its own reforms, as evidenced by the special committee's proposals. See, e.g., Danny Robbims, Hearing on Due Process Is Canceled, L.A. TMMES, Nov. 1, 1991, at C5; Teicher, supra note 262 , at D6.

308. For example, the governor of Illinois indicated that the state would be willing to reconsider the legislation if the NCAA adopts similar reforns. Illinois Due-Process Bill Is Signed, supra note 243 , at 2 . Florida has also indicated a willingness to eliminate the law if the NCAA adopts adequate reforms. Schultz Notes Some Progress with Legislatures, NCAA NEWS, Apr. 29, 1992, at 1.

309. See, e.g., 1991 Hearings, supra note 144, at 34-36 (testimony of Jerry Tarkamian).

310. Committee Releases Enforcement-Review Report, supra note 217, at 12. After all, the report recommends several due process reforns even though the current procedures would probably satisfy judicial due process scrutiny. See supra Section II(B).

311. 1991 Hearings, supra note 144 , at 10 (testimony of Creed C. Black). 


\section{CONCLUSION}

The popularity and profitability of collegiate athletics largely derives from the public's desire to watch athletes compete to be the best-under fair playing rules. Similarly, the public has forcefully demanded that the NCAA enforcement procedures also operate under fair rules. The NCAA has recently instituted due process reforms, and it is possible that the 1993 NCAA Convention will approve further due process protection for individuals and institutions under investigation by the NCAA. Although not required by the Supreme Court, these reforms will improve the fairness (perceived and actual) of NCAA enforcement regulations. Indeed, because public opimion is behind the current push for NCAA reform, it is imperative that the NCAA extensively publicize the reforms implemented. Specifically, the NCAA should make sure that both the public and the NCAA membership understand that current NCAA enforcement regulations satisfy most due process requirements, and that the procedural changes recently adopted and any amendments approved at the 1993 Convention will provide additional significant due process protection. The NCAA should also explam its decision not to support the current proposals for independent hearing officers and open hearings, and should imdicate that it will nonetheless continue to review these recommendations. Generally, the NCAA does play fair; it must now convince the public. 